\title{
Doctoral research on cadastral development
}

\author{
Cagdas, Volkan; Stubkjær, Erik
}

Published in:

Land Use Policy

DOI (link to publication from Publisher):

10.1016/j.landusepol.2008.10.012

Publication date:

2009

\section{Document Version}

Early version, also known as pre-print

Link to publication from Aalborg University

Citation for published version (APA):

Cagdas, V., \& Stubkjær, E. (2009). Doctoral research on cadastral development. Land Use Policy, 26(4), 869889. https://doi.org/10.1016/j.landusepol.2008.10.012

\section{General rights}

Copyright and moral rights for the publications made accessible in the public portal are retained by the authors and/or other copyright owners and it is a condition of accessing publications that users recognise and abide by the legal requirements associated with these rights.

- Users may download and print one copy of any publication from the public portal for the purpose of private study or research.

- You may not further distribute the material or use it for any profit-making activity or commercial gain

- You may freely distribute the URL identifying the publication in the public portal -

\section{Take down policy}

If you believe that this document breaches copyright please contact us at vbn@aub.aau.dk providing details, and we will remove access to the work immediately and investigate your claim. 


\title{
Doctoral research on cadastral development
}

\author{
Volkan Çağdaş,*, Erik Stubkjær ${ }^{\mathrm{b}, 1}$ \\ a Yildiz Technical University, Department of Geodetic and Photogrammetric Engineering, 34210 Istanbul, Turkey \\ b Aalborg University, Department of Development and Planning, 9220 Aalborg, Denmark
}

\section{A R T I C L E I N F O}

Article history:

Received 24 June 2008

Received in revised form

26 September 2008

Accepted 24 October 2008

\section{Keywords:}

Cadastre

Cadastral development

Cadastral system

Doctoral research

Land administration

Land registration

Land tenure

Property rights

Research methodology

Theory building

\begin{abstract}
A B S T R A C T
The multitude of rights in land and the recording of these rights are addressed by a number of studies, yet a recognized paradigm for such studies seems missing. Rights in land are recorded and managed through either cadastral systems or land administration systems depending on the legal system of the countries concerned. The cadastre, however, is the core of both systems as it provides for systematic and official descriptions of land parcels or real property units. The research mentioned often has a development perspective, and in this article we will motivate the introduction of the research domain of cadastral development. This research is multi-disciplinary and draws on elements of theories and methodologies from the natural, the social, the behavioral, and the formal sciences. During the last decade or so, doctoral dissertations have come to constitute a substantial part of this research effort. The article focuses on the methodological aspect of doctoral research by analyzing ten doctoral dissertations. Our analysis is based on a taxonomy of methodological elements and aims at identifying commonalities and differences among the dissertations in the use of concepts and methods. Having completed the main analysis, we invited the authors of the dissertations to comment upon our analysis of their work and the developed taxonomy. The responses corroborate the view that the taxonomy could be used for further analyses and provide for a framework for further doctoral research. The article concludes with a call for a shared terminology and a shared set of concepts which may contribute to further theory building within the cadastral domain.
\end{abstract}

(c) 2008 Elsevier Ltd. All rights reserved.

\section{Introduction}

This article analyzes ten doctoral dissertations from the methodological point of view in relation to land tenure, immobile property rights, and the recording of these rights by either cadastral systems or land administration systems. The overall aim is to demonstrate commonality in the methodological and theoretical aspects of these dissertations and to present a taxonomy which may be used for further analyses and indeed for guiding Ph.D. level students. We take care to define the concepts used. For scholars well versed in the subject matter, the amount of definitions may appear as superfluous. However, we think the amount is justified by our intention of introducing a specific research domain.

Land tenure is a legal term. It originates in English feudalism and refers to right(s) in land (Bruce, 1993, p. 1, 6). It has been defined as the rights, responsibilities, and restraints people have with respect to the use and benefit of land (Nichols, 1993, p. 31). Land tenure varies among countries and even within countries. However, a

\footnotetext{
* Corresponding author. Tel.: +90 212383 5313; fax: +90 2123835274 .

E-mail addresses: volkan@yildiz.edu.tr(V. Cağdas), est@land.aau.dk (E. Stubkjær).

1 Tel.: +45994083 50; fax: +4598156541.
}

broad classification distinguishes formal (statutory) from informal (customary) land tenure. In formal land tenure, rights, responsibilities, and restrictions in land are administrated according to a legal system, be it common law, civil law, or religious law. The legal source is stated in writing and judicial precedent mostly is of importance. On the other hand, informal land tenure is administrated by customs or oral traditions. Land tenure is managed by a land administration (Nichols, 1993, p. 41). The term has been used especially in countries where the common law legal system exists (e.g. United Kingdom, United States, Canada, Australia and other former colonies of the United Kingdom) to describe the processes of surveying and mapping, land registration, land conveyance, land valuation and taxation, regulation of land tenure, allocation of interests in land, dispute resolution, and land markets' (Nichols, 1993, pp. 60-91).

In Continental Europe, the term immobile property is used for referring to rights in land rather than the term land tenure. This conceptualization inherently assumes that rights in land include the responsibility and restrictions that accompany each right (Rakai, 2005, pp. 32-33). Moreover, property rights are recorded, more or less complete, through national information systems in terms of cadastre and land registry. Land registration means 'a process of official recording of rights in land through deeds or title (on properties)' (Zevenbergen, 2002, p. 1). Noting different interpretations 
of the term 'cadastre', Silva and Stubkjær (2002) find support for defining cadastre as 'a systematic and official description of land parcels, which includes for each parcel a unique identifier'. The description includes text records on attributes of each parcel. The prototypical means of identification is a large-scale map that provides information on parcel boundaries (p. 410). Cadastre and land registers were born and evolved separately; later a combination of these dual systems was dubbed cadastral systems (see Zevenbergen and Bogaerts, 2000; Silva and Stubkjær, 2002). However, as different countries interpret the term cadastre in different ways, United Nations Economic Commission for Europe (UNECE) introduced the term of land administration by the Land Administration Guidelines in 1996, particularly for countries in transition. Land administration was defined in the Guidelines as 'the processes of determining, recording and disseminating information about the tenure, value and use of land when implementing land management policies' ( $\mathrm{p}$. 107). It is considered to include land registration, cadastral surveying and mapping, fiscal, legal and multi-purpose cadastres and land information systems (Steudler, 2004, p. 15).

Although conceptions of cadastral systems and land administration vary among the countries, their basic function is similar, namely systematic and official recording of rights in land. The present article mainly focuses on this common function and uses the term of cadastral development for referring to the improvement of recordings of rights in land. The term of cadastral development was introduced by Silva and Stubkjær (2002), and defined by Silva (2005) as 'the processes of creating, reforming, improving or reengineering cadastres' (p. 13) [and cadastral systems].

During the last three decades, scientific research on cadastral development covering aspects of cadastral systems and later land administration systems has been increasing. These initiatives have been performed based on different theories and research methodologies. The research themes may be grouped according to branches of science as follows:

A. Natural sciences, i.e. including Geodesy, Physical Geography (Wilcox, 1984; Barnes et al., 2007; Mueller, 2008).

B. Social and behavioral sciences, i.e. including Economics, Law, Politics, Management and Sociology (Steudler et al., 1997; Kaufmann and Steudler, 1998; Williamson, 2001; Silva and Stubkjær, 2002; Steudler and Kaufmann, 2002; Ting, 2002; Zevenbergen, 2002; Park, 2003; Steudler et al., 2003, 2004; Törhönen, 2003a; Griffith-Charles, 2004; Steudler, 2004; Dalrymple, 2005; Silva, 2005; Rakai, 2005; Nkwae, 2006; Auzins, 2007; Rajabifard et al., 2007; Stubkjær et al., 2007; Vitikainen, 2007).

C. Formal sciences ${ }^{2}$, i.e. including Information sciences (Bittner, 2001; Oosterom and Lemmen, 2001; Effenberg, 2001; Bittner and Frank, 2002; Stoter and Oosterom, 2003; Stuckenschmidt et al., 2003; Navratil and Frank, 2004; Stoter, 2004; Tuladhar, 2004; Oosterom et al., 2006; Hess and Schlieder, 2007; Hess and Vaskovich, 2007; Navratil and Frank, 2007) and Systems sciences (Dale, 1979; Barnes, 1994; Barry, 1999; Zevenbergen, 2002; Ottens, 2004; Rakai, 2005; Nkwae, 2006; Ottens and Stubkjær, 2007).

Among these research efforts, the doctoral studies and their contributions constitute a substantial part. They are supposed to bring new knowledge to the research domain by describing the nature of a phenomenon, by developing a tool, a methodology, or a theory (Gile, 2001). In doctoral research, as well as in any scientific study,

\footnotetext{
2 Research regarding information sciences and system sciences was classified under the heading of the formal sciences, although some of them did not apply formal science methodologies.
}

these contributions and their validations mainly depend on the selected theories and applied methodologies. Despite the abovementioned fruitful contributions, from our point of view, a coherent and universal core cadastral theory and related research methodology have not been developed so far. The lack of a shared set of concepts and terminology, and the various research methodologies applied, motivated us to present a taxonomy of research methodology elements to support more precise communication among the researchers. For these purposes we use doctoral dissertations as an empirical base and analyze them from the methodological point of view. However, the intention is not to (re)evaluate the qualities of doctoral dissertations which were already reviewed by the supervisor(s) and defended by the researcher in front of the scientific committees. Rather, the overall aim is to demonstrate commonality in the methodological and theoretical aspects of these dissertations and to present a taxonomy which may be used for further analyses and indeed for guiding Ph.D. level students.

Noting the various themes of doctoral dissertations, we suggest the following broad classification:

1. Social and behavioral sciences aspects, i.e. Barry (1999), Ting (2002), Zevenbergen (2002), Park (2003), Törhönen (2003a), Griffith-Charles (2004), Steudler (2004), Dalrymple (2005), Rakai (2005), Silva (2005), Nkwae (2006).

2. Information sciences aspects, i.e. Bittner (2001), Effenberg (2001), Stoter (2004), Tuladhar (2004), Van Loenen (2006).

In this article, we analyze the following ten doctoral dissertations which all address social and behavioral sciences aspects of the research domain, more specifically land rights and the recording of land rights. They are written in the English language, defended during recent years, and available on the World Wide Web:

- Conceptual framework for modeling and analyzing periurban land problems in southern Africa by Nkwae (2006) at University of New Brunswick (Supervisor: Dr. S. Nichols),

- A neutral framework for modeling and analysing aboriginal land tenure systems by Rakai (2005) at University of New Brunswick (Supervisor: Dr. S. Nichols),

- Expanding rural land tenures to alleviate poverty by Dalrymple (2005) at University of Melbourne (Supervisors: Prof. I. Williamson and J. Wallace),

- Modeling causes of cadastral development - cases in Portugal and Spain during the last two decades by Silva (2005) at Aalborg University (Supervisor: Prof. E. Stubkjær),

- The impact of land titling on land transaction activity and registration system sustainability: a case study of St. Lucia by Griffith-Charles (2004) at University of Florida (Supervisor: Prof. G. Barnes),

- A framework for the evaluation of land administration systems by Steudler (2004) at University of Melbourne (Supervisor: Prof. I. Williamson),

- Sustainable land tenure and land registration in developing countries by Törhönen (2003a) at Helsinki University of Technology (Supervisor: Prof. K. Leväinen),

- The effect of adverse possession on part of a registered title land parcel by Park (2003) at University of Melbourne (Supervisor: Prof. I. Williamson),

- Principles for an integrated land administration system to support sustainable development by Ting (2002) at University of Melbourne (Supervisor: Prof. I. Williamson),

- Systems of land registration, aspects and effects by Zevenbergen (2002) at Delft University of Technology (Supervisors: Prof. Dr. Ir. M. J. M. Bogaerts and Prof. Dr. Ir. J. de Jong). 
We reviewed these dissertations according to their theme, problem statements and aims, cf. the section of 'The research domain of the reviewed dissertations'. In the next section, an analysis of the methodological and theoretical aspects of the selected dissertation is presented, based on a taxonomy regarding research methodology. It includes research method, data collection and analysis method, concept set and theories, and outcomes of the research. In the section 'Review of the draft taxonomy', we motivate a test of the acceptance of and agreement on the taxonomy within this part of the research community, and report on the outcome. The last section presents conclusions of the article.

\section{The research domain of the reviewed dissertations}

A major group of the reviewed dissertations regards land tenure reforms and accompanying land administration initiatives. During the recent decades, the World Bank and national development agencies have increased investment aiming at the formalization of informal land tenure through establishing individual title recorded in land administration systems. The underlying idea of these initiatives has been to provide economic growth by creating formal land markets. Do land titling and land administration projects really trigger economic growth? This question was empirically investigated by Feder and Onchan (1987) in Thailand and by Feder and Nishio (1999) in Asian, Latin American and African countries. According to their framework and empirical findings, land titling/land registration projects are providing economic growth by promoting access to credit. The degree of universal validity of these findings was tested by one of the reviewed doctoral dissertations, namely GriffithCharles (2004). In the case of Saint Lucia, she tested if land titling projects lead to the establishment of a formal land market and if this formal land registration system was sustainable over the medium term (p. 9). Based on her empirical findings, land titling/land registration is only one of several supportive factors that create an environment in which land markets would grow (p. 156).

Before colonization, in most places, i.e. Africa, Latin America and Asia, land was governed according to norms commonly known as tribal, traditional or customary land tenure. During the colonization, tracts of land were alienated from natives by European settlers and, subsequently, the territories divided into native reserves and 'Western' land. While traditional land tenure provisions remained operative in areas reserved for natives, statutory land tenure systems were imposed on 'Western' land (Kalabamu, 2000, pp. 305-306). In the post-colonization period, many land tenure reforms and accompanying land administration projects have been performed to replace informal tenure with formal tenure. Nonetheless, today in many places, tenure duality and related problems still exist. These problems became the research subject for the following dissertations: Nkwae (2006), Rakai (2005), Dalrymple (2005) and Törhönen (2003a). Their main interests relate to the question on how land tenure and land administration reforms should be designed for developing countries where different types of tenure systems exist. For instance, Rakai (2005) addressed the design and implementation of land tenure reforms for aboriginal communities in Canada. In accord with Rakai, in many countries, customary and/or aboriginal land tenure has been affected by Western type land tenure models, due primarily to the extension of European concepts and customs through colonialism (p. 7). For alleviating this 'tenure eurocentricity', the researcher proposed a culturally sensitive approach (pp. 4-5). Based on this approach, she aimed at designing land tenure models appropriate for the local needs of the aboriginal community in Canada. In the same vein, Nkwae (2006) investigated land tenure and land administration options to resolve periurban land problems in Southern Africa.
According to him, despite various conventional tenure reforms and land administration attempts there are still many periurban land problems prevailing in Southern Africa (p. 1). He claims that this failure is due to a misunderstanding of the requirements of Southern Africa. Therefore, he develops a strategy and a framework for evaluating land tenure and land administration options which meet the requirements of customary periurban areas (pp. 15-16).

Similar hesitations regarding success of conventional approaches are shared by Dalrymple (2005). According to her, current land administration systems focus (too) heavily on the delivery of individual tenure security. However, this approach does not support the objectives of sustainable development, because informal tenure in rural environments is inadequately addressed. Hence, she aims at establishing a land administration framework for delivering security according to people's interests and rights in land to suit the environmental and social needs of the rural poor in developing countries (p. 7). The last dissertation in this group is Törhönen (2003a). His overall aim was to define a framework of key issues underlying sustainable land tenure and land registration, and to analyze their relative impact on land administration and sustainable development in developing countries (p.6).

The next cluster of dissertations regards the recording of property rights and land tenure information by cadastral systems/land administration systems.

At the most basic level, a cadastral system can be considered strictly an information or record keeping system (Cashin and McGrath, 2006, p. 631). However, establishment and maintaining of cadastral systems do not only involve technical processes, but also involve political-economic and cultural processes (Sikor, 2006, p. 627). More precisely, which factors affect implementation or viability of the cadastral systems? Or why have some countries more developed cadastral systems than others? Silva (2005) tried to reply to these questions in the case of the Portuguese Cadastre. In accord with Silva, at the day of writing, Portuguese Cadastre did not include urban parcels, and it is covering only $14 \%$ of the rural parcels in the country (p. 2). This situation of underdevelopment compared to other well functioning cases in Europe, motivated her to search for mechanisms that may explain the difference between development and non-development cases. Thence the objectives of her research were to identify causes of cadastral development and as a consequence of this identification, to better understand why the Portuguese Cadastre did not developed and moreover to contribute to the explanation of cases taking place in other jurisdictions (p. 2). The other component of the cadastral system, namely the land registry and its aspects were investigated by Zevenbergen (2002) and by Park (2003). Zevenbergen approached the land registry from a systems approach and described its technical, legal, organizational, socio-cultural and financial-economical aspects. The main objective of the research was to identify the effect of the technical, legal, and organizational aspects and their interrelations on the functionality of the land registry (p. 20). Park focused on discrepancies in boundary descriptions and adverse possession of parts of a titled land parcel from the legal point of view. Adverse possession means the recognition of undocumented property rights founded upon long-term occupation or possession (p. 179). Adverse possession of a part of a parcel is achieved through the inadvertent trespass by one landholder over a portion of land which formally belongs to an adjoining landholder in a situation where a certain confusion reigns on location with regard to the correct position of the legal boundary dividing the two landholdings (p. 88). In some jurisdictions of Australia, change of boundary location may be achieved through adverse possession. In his research, Park aimed at developing a uniform and efficient model for dealing with the problems arising from an occupational boundary diverging from the legal boundary (p. 76). 
The last group of dissertations, namely Ting (2002) and Steudler (2004), regards land administration system for sustainable development and evaluation of land administration systems, respectively. Decision-making, which affects rights and responsibilities over land and its use, changes human-to-land relationships. To improve the decision-making process, a land administration system is required which moreover facilitates dialogue between government and its constituency and the flow of information about land tenure (Ting, 2002, p. 2, 296). According to Ting, current land administration infrastructures are not sufficiently based on these criteria (p. 2). Therefore, she aims at investigating what principles should guide the development of land administration infrastructures to adequately address the deliberations among stakeholders in order to better support sustainable development objectives ( $\mathrm{p}$. 3). A more empirical approach was chosen by Steudler (2004) in his evaluation of land administration systems. In recent years, the comparing and evaluation of cadastral systems and/or land administration systems have attracted attention both from international organizations and from the academics (see Williamson, 2001; Steudler and Kaufmann, 2002; Steudler et al., 2003, 2004; Steudler, 2004; Rajabifard et al., 2007). Nevertheless, currently there are no accepted methodologies and frameworks to compare and evaluate these systems at the international level (Steudler, 2004 , p. 3). This lack of an accepted evaluation methodology in the land administration field motivated Steudler to pursue the development of a methodology and a framework to measure and compare the performance of land administration systems in a context that includes factors such as economic, social, and environmental issues (Steudler, 2004, p. 4).

Concluding this section it appears that the basic, common attributes underlying the selected dissertations are (1) rights in land and (2) the recording of these rights. While only Silva (2005) focused on cadastre, the majority of dissertations including Nkwae (2006), Rakai (2005), Törhönen (2003a), Ting (2002) and Steudler (2004) studied land administration issues. However, there are substantial differences in relation to definition and interpretation of the concept of land administration among these dissertations. Two major approaches characterize these differences. The first approach defines land administration as a managerial or operational processes for implementing land policies (see Nkwae, 2006, p. 10; Dalrymple, 2005, p. 50, 63; Rakai, 2005, p. 40, Törhönen, 2003b, pp. 548-549). Researchers within this group addressed the management of land tenure (both formal and informal) in a community, referring to multi-disciplinary approaches. However, as appears from the following section on theories applied, the main theoretical base was theory on property rights and land tenure. Moreover, none of the reviewed dissertations referred to political or management sciences, nor substantially addressed managerial or policy issues. These observations are not meant to imply a critique of the dissertations, but rather to draw attention to a perhaps misleading reference to implementation of land policies. The second approach interprets land administration as management of information in relation to tenure, value and use of land (see Dalrymple, 2005, pp. 50, 63; Steudler, 2004, p. 15; Ting, 2002, p. 38; Zevenbergen, 2002, p. 2). The researchers within this group seem to use the concept of land administration as a synonym of 'multi-purpose cadastre' or 'land information system', which later became part of spatial data infrastructures. Concluding these observations we note that the research domain covered by the reviewed dissertations is well described with reference to either property rights and land tenure or with reference to spatial data infrastructures. The terms and definitions of 'land administration' and 'land administration system' are much used, but in our judgement ephemeral. We prefer 'cadastre' because the term relates to more than 200 years of history, it refers to an essential component of spatial data infrastructures and, moreover, relates to a legal tradition of systematization and codification.

\section{Methodological and theoretical aspects of the reviewed dissertations}

A scientific methodology is a system of explicit rules and procedures upon which research is based and against which claims for knowledge are evaluated (Frankfort-Nachmias and Nachmias, 1997, p. 13). In this article we use the term methodology as an umbrella term, covering research methods, data collection and analyzing techniques as well as research procedure which specify how inquiry is performed. Research methods, data collection and analysis techniques will be analyzed in the following subsections; here we review the research procedures applied in the dissertations.

\author{
Methodological elements \\ - literature review \\ - research design with selection of \\ - research method including pertinent theory \\ data collection techniques \\ o data analysis method \\ case(s) studied (or population) \\ research procedure \\ - presentation of outcome (claims and validation) \\ - discussion of findings and \\ - recommendations for further studies
}

All dissertations open with an extensive and well addressed literature review on core concepts and various theories. This step is followed by a research design which covers selection of research methods, corresponding data collection and analysis techniques as well as selection of case studies. Apart from the discursive element in soft systems methodology normative or discursive approaches (Addams and Proops, 2000; Nainggolan, 2007) were not recorded in the investigated dissertations. This may be related to the fact that researchers came from geodetic surveyor faculties. The theories underlying the research include system theory in Zevenbergen (2002), Rakai (2005) and Nkwae (2006), and 'urban economics theory' and 'land tenure theories' in Nkwae (2006). The research procedure, however, varied. Thus, Nkwae (2006), Dalrymple (2005), Rakai (2005), Griffith-Charles (2004), Park (2003) and Törhönen (2003a) firstly performed field studies in order to analyze the current situation of cases, and then developed their frameworks/models based on field study findings. On the other hand, Ting (2002), Zevenbergen (2002), Steudler (2004) and Silva (2005) gave priority to frameworks/models development, and then they tested their frameworks/models through the case studies. All research mentioned was completed with presentations of outcomes, discussion on findings, and recommendations for further studies.

\section{Research methods}

Research can be grouped into two different types: quantitative and qualitative. The difference regards the ways in which the data are collected and how many observations are made (Iversen, 2007). Griffith-Charles (2004) applied a mixed research incorporating quantitative (linear and logistic regression) and qualitative (case study) methods, whereas the remaining nine studies preferred qualitative methods. A quantitative research is characterized 
by identifying a population for which the researcher wants to draw conclusions (Iversen, 2007). It aims to simplify the complexity of observed phenomena through the use of mathematical models. Methods and data used in theory-based models test theories through an evaluation of statistical relations between the explanatory variables and the question in place. These models can also provide predictions, or simulate outcomes (Schneider, 2007). The other group, qualitative research, includes an array of attitudes toward and strategies for conducting inquiry which aims at discerning how human beings understand, experience, interpret, and produce the social world. Qualitative research typically includes, but is not limited to, discerning the perspectives of people (Sandelowski, 2007). Most common qualitative research methods include ethnographic research, action research, and case study research.

Ethnography is an analytic description or reconstruction of cultural scenes and groups. The purpose of ethnographic research is to both describe and interpret cultural behavior, to discern cultural patterns in the behavior observed (Barbour, 2006). It is conducted in the field for long durations of time, uses participant observation to collect data, and examines culture (Lahman and Geist, 2008). Another method within the qualitative research is action research. Action research is a strategy for addressing research issues in partnership with all possible stakeholders. Defining characteristics of action research are collaboration, mutual education, and action for change. It recognizes contextual factors within the research environment and takes into account the culture, gender, economic status, ability, and other factors that may influence research partners, results, and research communities. On the contrary to, case study and ethnographic research methods, action research may provide a solution for a stated problem (Gibson, 2003). Finally, the most common method among the qualitative approaches is case study research. A case study is an empirical inquiry that investigates a contemporary phenomenon within its real-life context when the boundaries between phenomenon and context are not clearly evident and in which multiple sources of evidence are used (Yin, 1989, p. 23). It provides an in-depth examination of entities that seeks further theoretical understanding and practical knowledge of some phenomenon (Bott, 2006). A case is the unit of study (Lewis-Beck, 2007). Therefore, a case study could regard an individual, a group, or an organization. The case study could also be about an event, such as the implementation of an information system. A research employing the case study method may employ single case or multiple cases. In this latter instance, conclusions could be determined based upon similarities and differences among the cases involved in the study (Hunter, 2004).

Among above-mentioned methods, case study approach was favored in all reviewed researches, as also observed by Silva and Stubkjær (2002). Griffith-Charles (2004) performed her quantitative analysis on a single case study, but the other nine researches applied multiple cases studies (see Table 1). For instance, in Nkwae (2006), three former British colonies, namely Botswana, Malawi and South Africa, were selected as cases so as to analysis and to evaluate land tenure and land administration reform options ( $p$. 16). In all countries, their land administration systems were developed in a context marked by periurban problems and customary land tenure (pp. 18-19). The main case in Rakai (2005) regards an aboriginal community in the province of Nova Scotia, Canada. For testing the validity of the developed framework of the main case, the researcher performed case studies of two aboriginal communities in the province of British Columbia, Canada, which share similar historical and geographical conditions as the main case. In her research, Rakai demonstrated cultural, social and political aspects of the land tenure systems in order to design alternative land tenure models for the local needs of the aboriginal community in selected jurisdictions. The Portuguese Cadastre was chosen as a main case in Silva (2005) to inquiry causes of cadastral development. Criteria for selection of contrasting cases were: (1) Main and contrasting cases should have similar economic, political, institutional, cultural contexts and, (2) Contrasting cases should provide for recent and/or well-documented development processes (pp. 22-23). Consequently, the Spanish Cadastre and the Portuguese Agricultural Parcel Identification System were selected as two contrasting cases for identifying the causes of (non) development. Silva documented geographical, organizational, and historical frameworks for each case, and inquired causes of (non) development by a model-based analysis on these cases. Dalrymple (2005) performed her research in three different Cambodian villages. The village selections were performed based on criteria including accessibility, development stage, resource characteristics, and land tenure system (p. 135). For the purpose of identifying traditional rural land tenures and needs of rural poor, Dalrymple (2005) described selected cases in terms of village profile (livelihood conditions, landscape, settlement, tenure arrangement), village development activities, land and resource tenure, and village concerns (economic, environmental, social).

In order to develop a land administration evaluation framework, Steudler (2004) chooses the land administration systems of Switzerland, Sweden, Latvia and Lithuania as multiple case studies. The main criteria used were availability of resources and time. Ting (2002) applied her case study research in New Zealand and New Brunswick, Canada, so as to inquiry how the legal and institutional infrastructures for land administration could be re-engineered to better support sustainable development objectives. In this selection she took into account the following criteria: the countries selected should have (1) established a land administration systems, (2) a political commitment to environmental issues, (3) a history of indigenous rights movements. Moreover, (4) the case countries should be accessible, and (5) the country's legal or institutional features should include a feature or innovation relevant to the research (pp. 116-117). Park (2003) focused on boundary change through adverse possession in Australian jurisdictions with different law. He selected three recent court cases involving boundary discrepancy and then applied those court cases to each jurisdictions for displaying differences between the jurisdictions (p. 27), claiming that these cases were representative of the various problems arising from adverse occupation and boundary discrepancies (p. 260). Zevenbergen (2002) performed his research in the Netherlands, Indonesia, Austria and Ghana based on the maximum variance of the investigated cases. The researcher analyzed land registration system in selected cases in terms of functional (procedures, identifiers, use of information technology, actors, type of system, practice), technical, legal, organizational, and development projects point of views. In order to assess impact of the land titling projects, Griffith-Charles (2004) preferred Saint Lucia as a case study. In the selection of case study, the researcher also considered generalization possibilities of the research findings to other similar jurisdictions. Lastly, in Törhönen (2003a), Zanibar, Zimbabwe, Cambodia and Finland were singled out as multiple case studies (p. 3).

The above review reveals that except for Griffith-Charles (2004), all doctoral dissertations preferred qualitative methods. Quantitative approach uses statistical processes and produces quantifiable, strength, objective and reliable results that can be generalized from the sample to the larger population. In spite of the few instances so far, this approach is appropriate for further research in the field of cadastral development which aims to inquiry correlations between variables or studied phenomenon, as applied in Griffith-Charles (2004). On the other hand, qualitative research is more appropriate for researchers who aim to explore and understand nature of 
Table 1

Case studies of the reviewed doctoral dissertations.

\begin{tabular}{|c|c|}
\hline Dissertation & Selected case \\
\hline Nkwae (2006) & Multiple: land tenure and land administration systems of Botswana, Malawi and South Africa \\
\hline Rakai (2005) & Multiple: land tenure in three aboriginal communities of Canada (Nova Scotia and British Colombia) \\
\hline Silva (2005) & Multiple: the Portuguese Cadastre, the Spanish Cadastre and the Portuguese Agricultural Parcel Identification System \\
\hline Dalrymple (2005) & Multiple: land tenure and natural resource management structure in three villages of Cambodia \\
\hline Steudler (2004) & Multiple: land administration systems of Switzerland, Sweden, Latvia, Lithuania \\
\hline Griffith-Charles (2004) & Single: land registration system and land market of Saint Lucia \\
\hline Park (2003) & Multiple: court cases involving boundary discrepancies from Australian jurisdictions \\
\hline Törhönen (2003a) & Multiple: land tenure in Zanibar, Zimbabwe land titling project, Cambodian cadastral project, Finland \\
\hline Ting (2002) & Multiple: land administration systems in New Zealand, New Brunswick, Canada \\
\hline Zevenbergen (2002) & Multiple: land registration systems of the Netherlands, Indonesia, Austria and Ghana \\
\hline
\end{tabular}

a being studied phenomena, as appeared from the remaining nine dissertations. However, as Geist and Lahman (2008) points out both qualitative and quantitative methods have weaknesses when used alone. For instance, in qualitative approach researchers may include their own interpretations and biases in the research. Similarly, quantitative research does not develop an in-depth description of the phenomena being studied. Therefore, combination of qualitative and quantitative approaches overcomes the limitations of single approaches and provides more comprehensive and stronger results.

As Silva and Stubkjær (2002) stated, the cadastral systems and land administration are dependent on social, economic and cultural factors that need to be understood and reflected in research on cadastral development (p. 411). Case study research method allows identifying and describing those factors and their relations. Therefore, researchers may benefit from this method to understand the existing cadastral systems before construction of models or the development of solutions (p. 414). Nkwae (2006), Dalrymple (2005), Rakai (2005), Park (2003), Törhönen (2003a), Ting (2002) and Steudler (2004) use case study method in that way, which is defined by Yin (2003) as descriptive case study. This group of dissertations identifies factors and relationships among the factors that affect phenomena being investigated. For instance, Rakai (2005) and Nkwae (2006) described cultural, social and political factors of land tenure and land administration systems. Likewise, Ting (2002) identified economical-political, legal, institutional, and technological factors that affect land administration systems in selected case studies. Finally, Steudler (2004) described and evaluated land administration systems according to political (i.e., legal framework), managerial (i.e., organizations), operational (i.e., procedures, services) and external factors (i.e., technology)(pp. 88-89). Summarily, factors described within this group of dissertations may be structured as follows: (1) geographical, environmental factors, (2) institutional factors (history, cultural framework, legal framework including formal and informal law, social relationships within a society); (3) stakeholders, their functions and powers (land registry, cadastre and other governmental organizations, parliaments, courts, private practitioners/professional, academics, households, parcel owners, non-governmental organizations/interest groups, and donor agencies); (4) procedures (i.e., adjudication, transfer, subdivision); and (5) technological factors (i.e., surveying and mapping devices, information systems). Differently from the descriptive case studies, Zevenbergen (2002) and Silva (2005), applied another type of case study so as to explain cause and effect relationships between the above-mentioned factors. This type is defined by Yin (2003) as an explanatory case study. For example, Zevenbergen (2002) looked for the relative importance of the functional, technical, legal, organizational aspects of the land registry in order to understand the effect of these factors on the functionality of the land registry, while Silva (2005) looked for resources, profit and degree of cooperation among stakeholders.
Concluding this section, it can be noted that the abovementioned two qualitative methods, namely ethnographic research and action research have potential that make them useful for particular type of research in the field of cadastral development. As Salamon, 1998 pointed out, any investigation of land tenure must take into account the culture of the people in the area, because culture shapes the physical world, and, correspondingly, culture is acted on by what it created (Salamon, 1998, p. 166, quoted from Rakai, 2005, p. 57). The ethnographic research may provide indepth description of human-to-land interrelationship in a society from the cultural point of view. This approach allows realizing culturally feasible and viable development projects, i.e. tenure formalization, land titling projects. Among the reviewed dissertations, importance of cultural aspects of land tenure and land administration was precisely addressed in Rakai (2005). Even though she did not apply a full ethnographic study, her case study research may be labeled as 'ethnographically informed' or 'ethnographically influenced research' (see Lahman and Geist, 2008). Other method within the qualitative approach, action research seems not conducted in the field of cadastral development so far. However, a very similar approach, namely soft system methodology has been applied to develop or to analyze reform options for land administration and land tenure in Rakai (2005) and Nkwae (2006). The soft system methodology will be detailed in 'Concepts and applied theories' section. The next section focuses on applied data collection and analysis methods in reviewed dissertations and discusses their appropriateness for further research in the field of cadastral development.

\section{Data collection and analysis methods}

There are a number of methods of data collection and analysis employed in quantitative and qualitative research. For instance, Yin (1989) identifies six methods of data collection often used in case study research. They are (1) documentation, (2) archival records, (3) interviews, (4) direct observation, (5) participant observation, and (6) physical artifacts. On the other hand, Blaikie (2000) classified data collection techniques according to two main classes as quantitative and qualitative data collection techniques. Quantitative techniques include (1) observation (structured), (2) questionnaire, (3) structured interviews, and (4) content analysis of documents. Qualitative techniques cover (1) participant observation, (2) observation (semi-structured and unstructured), (3) interview (focused, in-dept, group, oral-life histories) and (4) content analysis of documents.

\section{Data collection}

In this article, we classify data collection techniques more generally as (1) documentary, (2) interview, (3) questionnaire and (4) observation. An overview is provided by Table 2 below. The use of maps and other collection of spatial data apparently do not surface among applied data collection techniques. 
Table 2

Data collection methods and data resources of the reviewed doctoral dissertations.

\begin{tabular}{|c|c|c|c|c|}
\hline Dissertation & Documentary & Interview & Questionnaire & Observation \\
\hline Nkwae (2006) & $\begin{array}{l}\text { Scholarly literature (SL), } \\
\text { National legislation (NL), } \\
\text { Reports (R), Others (O) }\end{array}$ & $\begin{array}{l}\text { Government officials (GO), } \\
\text { Academics (AC) }\end{array}$ & $\begin{array}{l}\text { GO, AC, PP, NGOs, Staff of the } \\
\text { donor agencies }\end{array}$ & Direct observation in the field \\
\hline Rakai (2005) & $\begin{array}{l}\text { SL, NL, R, O, Ethnographic } \\
\text { writings }\end{array}$ & GO, Local community (LC) & - & - \\
\hline Silva (2005) & SL, NL, R, O & $\mathrm{GO}, \mathrm{AC}$ & - & Prior knowledge \\
\hline Dalrymple (2005) & SL, R, O & $\begin{array}{l}\text { GO, Land Management Project } \\
\text { staff, LC and household }\end{array}$ & - & $\begin{array}{l}\text { Direct and participant } \\
\text { observation in the field }\end{array}$ \\
\hline Steudler (2004) & SL, NL, R, O & $\begin{array}{l}\text { GO, AC, Private practitioners } \\
\text { (PP) }\end{array}$ & - & - \\
\hline Griffith-Charles (2004) & SL, NL, R, O & - & $\begin{array}{l}\text { Owners or de facto owners of } \\
\text { randomly selected parcels }{ }^{\mathrm{b}}\end{array}$ & - \\
\hline Park (2003) & SL, NL, R, O, Court decisions & - & - & - \\
\hline Törhönen (2003a) & SL, NL, R, O & $\begin{array}{l}\text { GO, AC, Courts members, Staff } \\
\text { of the non-governmental } \\
\text { organizations (NGOs), LC }\end{array}$ & Local community & $\begin{array}{l}\text { Direct and participant } \\
\text { observation }\end{array}$ \\
\hline Ting (2002) & SL, NL, R, O & $\begin{array}{l}\text { GO, AC, PP, NGOs, Interest } \\
\text { groups }\end{array}$ & $\begin{array}{l}\text { GO, AC, PP, NGOs, Interest } \\
\text { groups }\end{array}$ & \\
\hline Zevenbergen (2002) & SL, NL, R, O & GO, PP, AC & - & $\begin{array}{l}\text { Direct and participant } \\
\text { observation in relevant } \\
\text { organizations and field }{ }^{c}\end{array}$ \\
\hline
\end{tabular}

\footnotetext{
a Household interviews were performed with structured questionnaires (Dalrymple, 2005, p. 137).

b The interviews used for validation of documentary data (Griffith-Charles, 2004, p. 88).

c Applied very limited (Zevenbergen, 2002, p. 127).
}

The documentary data collection technique appears in a variety of forms. In our classification, it covers, e.g. archival, document and literature survey works. This technique is the most frequently applied data collection method among the reviewed dissertations; it was preferred in all of the ten cases. In all cases, documentary methods cover scholarly literature, national law and policy documents, technical and advisory reports from both national and international agencies, i.e. International Federation of Surveyors (FIG), United Nations, World Bank, International Monetary Fund, and other complementary data like statistical periodicals. In addition to these materials, Rakai (2005) utilized ethnographic writings of social science scholars. Usage of such kind of data sources enabled Rakai (2005) to represent description of human-to-land interrelationship in her case study from the cultural point of view.

Interview is a data collection method in which an interviewer questions people to elicit self-reports of their opinions, attitudes, values, beliefs or behaviors. Interviews are usually carried out in face-to-face situations although interactive television and on-line computers are also used (Sproull, 1995). It is the second frequently used technique, which was used by all reviewed researchers except Griffith-Charles (2004). Three types of interviews were applied: (1) structured, (2) unstructured and (3) semi-structured. Structured interviewing refers to a situation in which an interviewer asks each respondent a series of pre-established questions with a limited set of response categories (Pickard, 2007, p. 175). In a structured interview, strict adherence to the order and wording of the questions and the instructions is required (Sarantakos, 2005 , p. 268). Unstructured interviews are used to gain a holistic understanding of the thoughts and feelings of the interviewee. They are concerned with open-ended questions that allow the interviewees to tell their own story in their own words (Pickard, 2007, p. 175). Semi-structured interviews lie somewhere between the structured and unstructured types. They contain elements of both, with some being closer to structured interviews, and others closer to unstructured ones (Sarantakos, 2005, p. 269). Among the reviewed dissertations, interviews were performed by Rakai (2005) and Nkwae (2006) in an unstructured manner. The purpose of conducting unstructured interviews in Rakai (2005) is to put the interviewees at ease and so allow them to describe their experiences of traditional and current land tenure (p. 85). Semi-structured interviews were preferred in Steudler (2004), Silva (2005) and Ting (2002), even though they did not give explanation for this selection. On the other hand, Dalrymple (2005) applied both structured and semi-structured methods in her research. Interviewees generally were senior or key officials of the relevant organizations. In all cases, except Griffith-Charles (2004) and Dalrymple (2005), university staff or academics were also interviewed. Moreover, Steudler (2004), Ting (2002) and Zevenbergen (2002) questioned surveyors and advisors from the private sector. Merely in Dalrymple (2005), Törhönen (2003a) and Ting (2002), local community or household's approaches were taken into consideration based on information gained through interviews. Besides, Törhönen (2003a) made interviews of courts members and staff of non-governmental organizations.

Observations, including participant and non-participant (direct) observations, come as the third data collection techniques. According to Platt (2007), participant observation is a method of data collection in which the investigator uses participation in an area of ongoing social life to observe it. Participant observation requires that the researcher becomes member of the phenomenon being observed. On the other hand, in non-participant observation the researcher watches the subjects of his or her study, with their knowledge, but without taking an active part in the situation under scrutiny (Marshall, 1998). Observation techniques which were performed by Nkwae (2006), Silva (2005) and Zevenbergen (2002) seem to be used as a supplementary method. However, Törhönen (2003a) used both participant and direct observation techniques effectively. Also, Dalrymple (2005) combined observations with interviews to identify and measure how needs of people varied with their environments. This approach provided her a close connection with the subjects and first hand observation of them interacting in their environment (p. 131).

Questionnaire is the fourth most preferred data collection techniques among the reviewed dissertations. They are prepared in such a way that respondents can complete them without any assistance other than built-in and/or separate written instructions (Blaikie, 2000, p. 233). In general, questionnaires can be classified as (1) standardized, (2) un-standardized and (3) semi-standardized. Standardized questionnaires have a highly rigid structure and are not allowing any flexibility in answering the questions. On the 
other hand, un-standardized ones are less rigid and the degree of standardization is fairly low. This type of questionnaire allows respondents to formulate their answers the way they want. The semi-standardized type can be placed between the two other types, combining a moderate degree of structure and standardization (Sarantakos, 2005). Among the ten cases, Griffith-Charles (2004) applied standardized questionnaires to owners or de facto owners of randomly selected parcels for verifying data derived from land registry records. As mentioned above, this method was the best data collection technique for her quantitative study. Also Ting (2002) used semi-standardized questionnaire to obtain basic background information and to introduce the interviewee to the topics to be covered in the face-to-face interview. Data collection methods and data resources of the reviewed dissertations are summarized in Table 2.

Data collection is prone to unexpected difficulties and several researchers reported on problems and limitations which they met while performing their field studies. For instance, the interview request of Nkwae was refused by some people who were afraid of talking on issues which had political sensitivity. Moreover, the researcher did not visit some places due to safety concerns (Nkwae, 2006, p. 224). Silva suffered from unwillingness among politicians to co-operate (Silva, 2005, p. 7). A main restriction for Steudler was insufficient time and budget (Steudler, 2004, p. 144). In addition to these, Dalrymple reported on the language barrier as a research constraint (Dalrymple, 2005, p. 135).

Summarizing this section, it appears that the majority of the dissertations demonstrated multiple data collecting techniques, as it can be seen from Table 2 . A combination of documentary and interview techniques seems the foremost data collection methods among the applied case studies. Documentary method enabled researchers to demonstrate knowledge of the current state of the art. Also interviews provided them to obtain opinions and feelings of stakeholders about the phenomenon of interest with either a flexible (unstructured and semi-structured) or a strict manner (structured). Questionnaires are used to collect data especially in quantitative research, for instance as demonstrated by GriffithCharles (2004). They differ from interviews as they do not require presence of an interviewer. Therefore, questionnaires have advantages when cheap, quick and large sample of data collection is feasible. Observation techniques are one of the useful data collection methods especially in case study and ethnographic research, even though there have been some argument on their objectivity. Generally, as proposed by Schneider (2007), subjectivity may be alleviated through supplementary data collection methods. For instance, Dalrymple (2005) synthesized data obtained by observations (e.g. field notes) with other types of data (e.g. questionnaires, interviews) to create a more complete understanding of the complexities of the cases being studied. The issue of objectivity of knowledge is further addressed in the following.

\section{Data analysis}

Intrinsically, Griffith-Charles (2004), who was performing a quantitative analysis, used statistical procedures to draw conclusions and support the findings. Chi-square measures of relationships between variables were used to determine the factors that mitigated the anticipated impact of the land registration and titling program on the land market in the case study area. Also, logistic regression was used to determine relative impacts of the various factors on the incidence of land transactions (p. 89). Among those who preferred qualitative methods, only two studies mention the application of data analysis methods, namely Stakeholder Analysis in Silva (2005) and SWOT Analysis in Steudler (2004). A stakeholder analysis aims at the identifica- tion of allies and adversaries relative to project implementation. It comprises mainly the identification of the stakeholders and the assessment of their interests and of how these interests will affect the project's viability. Even though the method has been applied in different areas by several international donor organizations, the analysis was firstly applied to cadastral domain for explaining causes of cadastral development by Silva (2005, p. 43). The other data analysis method, or indeed a strategic planning tool, SWOT (Strengths, Weaknesses, Opportunities, Threats) analysis was used by Steudler (2004). Having applied the evaluation framework, the researcher performed a SWOT analysis for demonstrating strengths, weaknesses, opportunities and threats of each evaluated land administration system in a structured manner. Summarizing, it can be noted that a major part of the dissertations applying qualitative research did not address data analysis issues, although there are several techniques available in the literature for qualitative research, i.e. content analysis, interpretive phenomenological analysis, narrative analysis, discourse analysis (see Langhout, 2005).

\section{The outcome of the reviewed dissertations}

Science is taken here to be a systematic, rule-bound, collective exploration of reality. Individual research efforts are supposed to contribute to such exploration by adding and/or correcting and/or consolidating either knowledge or a potentially useful tool for knowledge acquisition. In concrete terms, such contributions can take three forms: (1) empirical contributions, (2) conceptual ('theoretical') contributions, and (3) methodological contributions. Empirical contributions can be discovery of unknown physical, social and behavioral entities and/or the unveiling of facts describing their nature and behavior. Another type of contribution is conceptual, in the form of new or modified theories, new questions, new hypotheses to test, new analyses of known facts or findings. Methodological contributions can materialize as new experimental designs, statistical procedures, the development of metrics, of measurement tools, of analytical procedures, of classification and categorization tools (Gile, 2001, pp. 2-3).

In this article we selected contributions to the research domain as a first criterion and analyze outcomes according to their contributions (cf. Claims of new knowledge); then we assess outcomes based on another criterion, namely validity (cf. Validation of the new knowledge). Empirical, methodological and theoretical contributions of the reviewed dissertations are summarized in Table 3.

\section{Claims of new knowledge}

Both Rakai (2005) and Nkwae (2006) developed a conceptual analytical framework based on soft system methodology. The former used this framework for analyzing current land tenure systems and reform options in aboriginal communities of Canada, likewise the latter used his framework for identifying and analyzing periurban land problems in Southern Africa. In addition to their methodological contributions, they also made some empirical and theoretical contributions to the research domain. From the theoretical point of view, both of them preferred a multi-disciplinary approach by using theory and approaches from law, anthropology, urban planning, geomatics engineering, and systems engineering disciplines. Another dissertation under this theme, Dalrymple (2005) provided a methodological contribution by developing a land administration framework which intended to enable sustainable development and poverty alleviation.

As mentioned before, Silva (2005) aimed at defining the mechanisms which affect the viability or improvement of the cadastre, and then tested the validity through the selected case studies in Portugal and Spain. The research provided a theoretical contribu- 
Table 3

Contributions of the reviewed dissertations.

\begin{tabular}{|c|c|c|c|}
\hline Dissertations & Empirical contributions & Methodological contributions & Theoretical contributions \\
\hline \multirow[t]{2}{*}{ Nkwae (2006) } & \multirow[t]{2}{*}{$\begin{array}{l}\text { Periurban land } \\
\text { problems were defined } \\
\text { in Southern Africa. }\end{array}$} & $\begin{array}{l}\text { Periurban land problems were } \\
\text { analyzed with soft system } \\
\text { methodology. }\end{array}$ & $\begin{array}{l}\text { Periurban land problems were defined with an } \\
\text { multi-disciplinary approach including } \\
\text { anthropology, urban planning theory, } \\
\text { geomatics engineering and soft systems } \\
\text { engineering. }\end{array}$ \\
\hline & & $\begin{array}{l}\text { Land tenure and land administration } \\
\text { requirements/options were analyzed } \\
\text { with a conceptual framework } \\
\text { developed by soft system methodology. } \\
\text { A design strategy for land tenure and } \\
\text { land administration reforms was } \\
\text { developed. }\end{array}$ & $\begin{array}{l}\text { Contradictions between customary and } \\
\text { statutory land tenure were analyzed by legal } \\
\text { pluralism concept }\end{array}$ \\
\hline Rakai (2005) & $\begin{array}{l}\text { Current land tenure systems and reform } \\
\text { options in Aboriginal communities of Canada } \\
\text { were defined. }\end{array}$ & $\begin{array}{l}\text { Land tenure and land administration } \\
\text { requirements/options were analyzed } \\
\text { with a conceptual framework } \\
\text { developed by soft system methodology. }\end{array}$ & $\begin{array}{l}\text { Aboriginal land tenure reform requirements } \\
\text { were defined with a multi-disciplinary } \\
\text { approach including anthropology, geomatics } \\
\text { engineering and soft systems engineering. }\end{array}$ \\
\hline Silva (2005) & $\begin{array}{l}\text { Mechanisms that constitute causes of cadastral } \\
\text { development were inquired in cases of } \\
\text { Portugal and Spain. }\end{array}$ & $\begin{array}{l}\text { A model-based method of analysis was } \\
\text { developed for assessing the } \\
\text { possibilities of success of development } \\
\text { projects regarding cadastres. }\end{array}$ & $\begin{array}{l}\text { A theoretical model, namely Profit + Resources } \\
\text { Model was created and used for explaining } \\
\text { causes of the cadastral development. }\end{array}$ \\
\hline Dalrymple (2005) & $\begin{array}{l}\text { People-land relationships among subsistence } \\
\text { societies in rural Cambodia were investigated. }\end{array}$ & $\begin{array}{l}\text { A land administration framework was } \\
\text { developed for sustainable } \\
\text { development and poverty alleviation. }\end{array}$ & - \\
\hline Steudler (2004) & $\begin{array}{l}\text { Land administration systems were evaluated in } \\
\text { cases of an array of Western Europe and Baltic } \\
\text { countries. }\end{array}$ & $\begin{array}{l}\text { A framework and a methodology for } \\
\text { evaluating land administration systems } \\
\text { were developed. }\end{array}$ & - \\
\hline Griffith-Charles (2004) & $\begin{array}{l}\text { Impact of land titling on market transaction } \\
\text { and the sustainability of land registration were } \\
\text { investigated in case of Saint Lucia. }\end{array}$ & $\begin{array}{l}\text { A mixed approach combining } \\
\text { quantitative and qualitative research } \\
\text { methods were applied for testing } \\
\text { property and land tenure theories. }\end{array}$ & - \\
\hline Park (2003) & $\begin{array}{l}\text { Law and schemes in relation to resolve } \\
\text { boundary discrepancy and adverse possession } \\
\text { as to part parcel were analyzed in case of } \\
\text { Australian states. }\end{array}$ & $\begin{array}{l}\text { A model for solving problems } \\
\text { regarding boundary variation by part } \\
\text { parcel adverse possession on } \\
\text { registered parcels was developed. }\end{array}$ & - \\
\hline Törhönen (2003a) & $\begin{array}{l}\text { Land tenure and land administration systems } \\
\text { were analyzed in an array of developed and } \\
\text { developing countries. }\end{array}$ & $\begin{array}{l}\text { A framework for sustainable land } \\
\text { tenure and land registration was } \\
\text { developed. }\end{array}$ & - \\
\hline Ting (2002) & $\begin{array}{l}\text { Institutional and legal aspects of land } \\
\text { administration systems in cases of New } \\
\text { Zealand and New Brunswick (Canada) were } \\
\text { identified. }\end{array}$ & - & $\begin{array}{l}\text { Role of land administration systems in } \\
\text { sustainable development was examined with a } \\
\text { multi-disciplinary approach including history, } \\
\text { environmental, planning, humanities and } \\
\text { economics studies. }\end{array}$ \\
\hline Zevenbergen (2002) & $\begin{array}{l}\text { Aspects of land registration } \\
\text { systems and their interrelations } \\
\text { were investigated in cases of an } \\
\text { array of developed and developing } \\
\text { countries. }\end{array}$ & - & $\begin{array}{l}\text { Models for land registration were developed } \\
\text { based on system theory. } \\
\text { The concept of trustworthiness was proposed } \\
\text { for evaluating overall qualification of a land } \\
\text { registration. }\end{array}$ \\
\hline
\end{tabular}

tion, namely a 'Profit + Resources Model' and a methodological tool namely 'a model-based analysis method'. The Profit + Resources Model asserts that cadastral development depends on the existence of a development agent who combines a perception of profit to be gained from the development of the cadastre, with the adequate resources to carry it out. The model also underlines that development will happen only if it is not counteracted by (stronger) opposition from other stakeholders (pp. 169-170). Silva related causes of development to stakeholder configurations, but Törhönen (2003a) took a more general point of view, assuming that the viability of a land administration system requires good governance, adequate resources, a culturally sensitive approach, equity, quality and commitment. According to his approach, the best solution may be obtained with a stated land policy, a simple and unified land administration organization, the recognition of customary tenure, and either sporadic or systematic but fair and gradually improved deed registration (p. 19).

The role and importance of the land registry was investigated by Griffith-Charles (2004) and Zevenbergen (2002) from different aspects. Griffith-Charles inquired whether land titling/land registration projects increase the volume of market transaction in the case of Saint Lucia. Her quantitative empirical findings indicate that the presence of a registration system in the case area did not induce a larger volume of formal transactions. In addition to this, a previously performed land titling project did not lead to increased credit use, increase in intensity of agricultural land use, or demand for individualization, despite providing increased formal tenure security (p. 155). Based on the case study findings and conclusions of other studies, the researcher asserted that land titling/land registration is only one of several supportive factors that create an environment in which land markets might grow ( $\mathrm{p}$. 156). The second dissertation concerned with land registration is Zevenbergen (2002). He provided a theoretical contribution to the research domain by developing land registration models based on system theory. In his research, land registration was described from both a static and a dynamic system view. Whilst the static system concentrates on describing which information is kept and how, the dynamic one concentrates on the three functions of adjudication, transfer of whole parcels, and subdivision. He also introduced the concept of 'trustworthiness' which may be used to evaluate overall qualification of a system of land registration. The concept indicates whether the land registry system achieves its societal 
goal(s); if people trust it and are willing (and able) to use it ( $\mathrm{p}$. 114). Lastly, another research theme closely related to land registration, namely adverse possession, was addressed by Park (2003). As mentioned earlier, Park aimed at developing a uniform model for solving problems regarding boundary variation by adverse possession in Australia. His research was concluded with a model including propositions related to both whole parcel adverse possession and to resolve boundary discrepancies. One of the propositions of his model is to absolutely and expressly prohibit the acquisition of title based upon part parcel adverse occupation (pp. 257-258).

Aspects of land administration systems were analyzed by Steudler (2004) and Ting (2002). Steudler provided a methodological contribution to the research domain by developing a framework and a methodology to measure performance of land administration systems. His framework consists of following five 'evaluation areas' which were defined based on responsibilities and tasks of relevant stakeholders in land administration systems: (1) policy level, (2) management level, (3) operational level, (4) external factors and (5) review process. According to the framework, these areas are evaluated by 'evaluation aspects' and 'good practices'. Evaluation aspects are performance indicators of key variables such as quality, time, and cost in fiscal, social, cultural and environmental terms. Good practices refer to criteria, which are representing a presumed 'ideal' system (p. 75). Steudler developed evaluation aspects and good practices mainly based on previously proposed functional criteria for cadastre, land registry, land administration and land information systems including Simpson (1976), Holstein (1987), McLaughlin and Nichols (1987), FIG (1995), Bogaerts (1999), Kaufmann and Steudler (1998), and Williamson (2001). He also took into consideration other aspects, i.e. principles of sustainable development, e-governance, and civic participation (pp. 84-87). In addition to evaluation framework, Steudler (2004) suggested a methodological procedure consisting of following steps for the evaluation of land administration systems: (1) review of the evaluation aspects in the evaluation framework, (2) establish 'good practice' for each aspect in the evaluated system's context, (3) identify performance gaps, (4) establish a summary profile (p. 102). The other dissertation in this group, Ting (2002), concluded her research by proposing an array of principles on legal, institutional and technical aspects of land administration systems which are supposed to facilitate governance and information sharing between the stakeholders to better support sustainable development objectives. With this study, the researcher also provided a theoretical contribution by applying a multi-disciplinary approach to examine the role of land administration in sustainable development (pp. 37-71).

\section{Validation of the new knowledge}

The other evaluation criterion for the research findings is the validation. Validity is the extent to which the research can be said to produce an accurate version of the world (Bloor and Wood, 2006, p. 147). When considering the validity of the conclusions of a research, two types of inferences are involved. The first of these is the internal validity of the study. This is the degree to which the investigator's conclusions correctly portray the data collected. The other inference concerns external validity (also referred to as generalizability). This is the degree to which conclusions are appropriate to similar populations and locations outside of the study area (Bloor and Wood, 2006, p. 148). Some of the above-mentioned outcomes were validated by the researchers (see Table 4). Silva (2005), Rakai (2005) and Park (2003) provided internal validation by testing their models and frameworks through subsequent case studies. Griffith-Charles (2004) internally validated her research by testing significance of results statistically. On the other hand, Dalrymple (2005), Törhönen (2003a) and Ting (2002) did not make explicit statements regarding the internal validity of their outcomes. Because of the time constraints, also Steudler (2004) did not test his evaluation framework and results (p. 151). Between these extremes, Nkwae (2006) validated the philosophical underpinning of his framework internally by interviews made with various stakeholders (pp. 70, 223). Similarly, Zevenbergen (2002) provided a limited internal validation based on information obtained from the land registry organizations in the studied countries (p. 128).

In terms of external validity or generalizability, researchers who applied case study method did not efficiently present whether their findings can be generalized from the study area to similar areas. To some extent, this is due to the nature of the case study research. As stated by Bott (2006), the most common argument against the use of the case study method is the lack of generalizability of findings because of the context specific focus and sample. We did however find some of generalization in the reviewed dissertations. For instance several researchers claim the applicability of their models and frameworks in other cases, although some of them did not provided strong argument for these claims; for analyzing land management reform requirements, designing and implementing land policies (Nkwae, 2006, p. 220); for assessing cadastral development projects (Silva, 2005, p. 172); for evaluating land tenure reform requirements and the designing and implementing land tenure reforms (Rakai, 2005, p. 198); for evaluating impact of land titling on land market (Griffith-Charles, 2004, p. 75); and for solving boundary discrepancy problems causing from part parcel adverse occupation (Park, 2003, p. 267). Mention is made that the issue of objectivation of knowledge was hardly addressed.

\section{Concepts and applied theories in the reviewed dissertations}

A theory is a set of concepts plus the interrelationships that are assumed to exist among these concepts (Blaikie, 2000, p. 142). A concept is an idea that is expressed in words or as a symbol (Blaikie, 2000, p. 129). Concepts enable effective communication, introduce a point of view, are means for classification and generalization, and serve as the building blocks of propositions, theories and hypotheses.

Theoretical activities have been classified into a numbers of levels. For instance Frankfort-Nachmias and Nachmias (1997) propose a four level classification:

- The lowest level of theorizing is an ad hoc classificatory system. It consists of arbitrary categories constructed in order to organize and summarize empirical observations.

- The second level of theory is a categorical system, a taxonomy. A taxonomy consists of a system of categories constructed to fit empirical observations in such a way that relationships among the categories can be described. The goal of a taxonomy is to provide an orderly schema for classification and description.

- The third level of theory is a conceptual framework. In a conceptual framework, the descriptive categories of second level are systematically placed in a structure of explicit propositions, statements of relationships between two or more empirical properties, to be accepted or rejected.

- The fourth level of theory is a theoretical system. It combines taxonomies and conceptual frameworks by relating descriptions, explanations, and predictions in a systematic manner. This is the highest level of theory and requires the most rigorous definitions (pp. 37-39).

In Table 5, we tentatively classify the theoretical elements and outcomes of the reviewed dissertations according to the abovesummarized criteria. 
Table 4

Internal validation of the reviewed dissertations.

\begin{tabular}{|c|c|c|c|}
\hline \multirow{2}{*}{$\begin{array}{l}\text { Research procedure, cf. the section 'Methodological and } \\
\text { theoretical aspects of the reviewed dissertations' }\end{array}$} & \multicolumn{3}{|c|}{ Internal validation } \\
\hline & Explicit & Commented & Not explicit \\
\hline Data collection, then modeling & $\begin{array}{l}\text { Rakai (2005) } \\
\text { Park (2003) }\end{array}$ & $\begin{array}{l}\text { Nkwae (2006) } \\
\text { Törhönen (2003a) }\end{array}$ & Dalrymple (2005) \\
\hline Modeling, then data collection & Silva (2005) & $\begin{array}{l}\text { Steudler (2004) } \\
\text { Zevenbergen }(2002)\end{array}$ & Ting (2002) \\
\hline Statistical analysis & & Griffith-Charles (2004) & \\
\hline
\end{tabular}

Nkwae (2006), Rakai (2005), Griffith-Charles (2004), Törhönen (2003a) draw upon the following theories articulated by other research communities: 'property and land tenure theories', 'urban economics theory' and 'planning theory'. As these theories belong to other scientific communities, we did not attempt to classify them here according to the above given criteria. Dalrymple (2005) draws on 'land administration theory' in her research (pp. 7, 43, 242, 243). However, as the content of the 'land administration theory' was not explicitly introduced by the researcher, we were not able to relate it to one of the above four levels. In Table 4 the research was ad hoc classified and placed in an additionally created new level (L0).

The evaluation approach of Steudler (2004) and the Profit+Resources Model of Silva (2005) were placed at the first level of theorizing. According to Steudler, 'evaluation is a transdiscipline or pseudo discipline, lacking clear research methods and methodologies' (p. 39). In this theoretical activity, categories, i.e. evaluation components, evaluation criteria, and evaluation metrics, were defined in an arbitrary manner. Also, they were not derived from any theory. Silva explained the inherent mechanisms that generate events, namely 'causal powers' (Danermark et al., 2002, p. 198) in the case of cadastral development phenomena by the Profit + Resources Model. In this theoretical activity, the main categories of the model (stakeholder, resource and profit) were defined arbitrarily and not derived from any theory as well. Therefore, we relate the 'evaluation approach' and the Profit+Resources Model to the first level of theorizing, namely ad hoc classification. Even though Silva did not explicitly state it, her theoretical model could be related to system theory, in so far as stakeholders could be taken as system elements, and their resources (i.e. technical ability and political powers) could be evaluated as attributes of system elements.

System theory enables the description and analysis of a group of entities which comprises a whole and which produces some results. The theory provides for a taxonomy which allows for describing observed phenomena in terms of a system, the system components and conceptual relationships between these components. We do not find it appropriate to classify system theory as an ad hoc classificatory system or a conceptual framework. System theory is not an ad hoc classificatory system, inasmuch as it provides an orderly schema for classification and description of empirical phenomena.
However, system theory is not a conceptual framework, since it does not require an explanation or prediction regarding observed phenomena. Therefore, in this article system theory was evaluated as a second level of theory, namely a taxonomy or categorical system.

System theory, its approaches and methodologies have been applied to the cadastral domain for a long time by, i.e. Dale (1979), Nichols (1993), Barnes (1994), Barry (1999), Barry and Fourie (2002), Zevenbergen (2004), Ottens (2004), Stubkjær (2006), Ottens and Stubkjær (2007). Furthermore, three of the reviewed dissertations apply the systems theory, namely Zevenbergen (2002), Rakai (2005) and Nkwae (2006). Zevenbergen (2002) wanted to approach land registration as much as possible as a whole and therefore applied a systems approach, studying the relations between the elements of the system and the common goal this wholeness is aimed at (pp. 13, 87). Systems may be analyzed or developed according to two main approaches of system engineering: hard system methodology and soft system methodology (SSM). The hard system methodology is appropriate in situations where there is an agreement on definition of problem and system objectives (i.e. software, hardware development). On the contrary to that, SSM is preferred in complex situations where there is no clear problem and well-defined objectives. SSM was introduced by Checkland (1981) and defined by Checkland and Scholes (1990) as 'an organized way of tackling messy situations in the real world. It is based on systems thinking which enables it to be highly defined and structured, but is flexible in use and broad in scope' (p. 1). Summarily, SSM proposes a recursive process in order to develop a design or analysis consistent with the environment of the system. Soft systems thinking consider human behavior and the parties' various perspectives, and also accommodates for a system environment that includes social, cultural, and economic factors. Barry and Fourie (2002) suggested the use of SSM for understanding and analyzing land management and cadastral systems during a period of rapid change (p. 32). Among the reviewed dissertations, Rakai (2005) and Nkwae (2006) successfully applied SSM in their case studies for identifying and analyzing land tenure and land administration reform options, although with different purposes. As demonstrated by the mentioned authors, in a cadastral development project SSM may indeed support project management;

Table 5

Applied theories in the reviewed dissertations.

\begin{tabular}{|c|c|c|}
\hline Level of theory & Theory domain & Research \\
\hline L2: Categorical system, taxonomy & System theory & Nkwae (2006) (soft system), Rakai (2005) (soft system), Zevenbergen (2002) \\
\hline L1: Ad hoc classificatory system & $\begin{array}{l}\text { Profit }+ \text { Resources Model } \\
\text { Evaluation approach }\end{array}$ & $\begin{array}{l}\text { Silva (2005) } \\
\text { Steudler (2004) }\end{array}$ \\
\hline L0: Not explicitly identified & Land administration theory & Dalrymple (2005) \\
\hline $\begin{array}{l}\text { Theories articulated by other research } \\
\text { communities }\end{array}$ & $\begin{array}{l}\text { Property and land tenure theories } \\
\text { Urban economics theory } \\
\text { Planning theory }\end{array}$ & $\begin{array}{l}\text { Nkwae (2006), Rakai (2005), Dalrymple (2005), Griffith-Charles (2004), } \\
\text { Törhönen (2003a), Ting (2002) } \\
\text { Nkwae (2006) } \\
\text { Nkwae (2006) }\end{array}$ \\
\hline
\end{tabular}


Table 6

Several definitions for 'cadastre' concept used in reviewed dissertations.

\begin{tabular}{|c|c|c|c|c|}
\hline & \\
\hline & Object of record & Content and attributes & Status and structure & Coverage \\
\hline \multirow[b]{2}{*}{$\begin{array}{l}\text { Cadastre is a methodically arranged public } \\
\text { inventory of data concerning properties } \\
\text { within a certain country or district, based on } \\
\text { a survey of their boundaries. Such properties } \\
\text { are systematically identified by means of } \\
\text { some separate designation. The outlines or } \\
\text { boundaries of the property and the parcel } \\
\text { identifier are normally shown on large scale } \\
\text { maps which, together with registers, may } \\
\text { show for each separate property the nature, } \\
\text { size, value and legal rights associated with } \\
\text { the parcel. It gives an answer to the questions } \\
\text { 'where' and 'how much' (Zevenbergen, 2002, } \\
\text { p. } 29 \text { quoting from Henssen and Williamson, } \\
\text { 1990, p. 20). }\end{array}$} & \multirow[t]{2}{*}{ Properties } & Maps and registers (text records) & $\begin{array}{l}\text { A methodologically arranged public } \\
\text { inventory based on systematic } \\
\text { identification of properties }\end{array}$ & $\begin{array}{l}\text { The properties within a country or } \\
\text { district }\end{array}$ \\
\hline & & $\begin{array}{l}\text { Maps: identification and boundaries of } \\
\text { properties } \\
\text { Text records: identification number, } \\
\text { and several attributes concerning } \\
\text { properties (nature, size, value and legal } \\
\text { rights associated with the parcel) }\end{array}$ & & \\
\hline $\begin{array}{l}\text { Cadastres are registers of rights over and } \\
\text { attributes of definable areas of land (Ting, } \\
\text { 2002, p. 39). }\end{array}$ & $\begin{array}{l}\text { Rights over and attributes of definable } \\
\text { areas of land }\end{array}$ & - & - & - \\
\hline $\begin{array}{l}\text { A cadastre is a systematic description of the } \\
\text { land units within an area. The description is } \\
\text { made by maps that identify the location and } \\
\text { boundaries of every unit. In the records, the } \\
\text { most essential information is the } \\
\text { identification number and the area of the } \\
\text { unit, usually differentiated by land use class. } \\
\text { Furthermore, the classical cadastre provides } \\
\text { information concerning owners, land classes } \\
\text { and values or land taxes (Steudler, 2004, pp. } \\
\text { 13-14). }\end{array}$ & Land units & $\begin{array}{l}\text { Maps and text records } \\
\text { Maps: identification of location and } \\
\text { boundaries of land units } \\
\text { Text records: identification number, } \\
\text { area, and several attributes concerning } \\
\text { land units (owners, land classes and } \\
\text { values or land taxes) }\end{array}$ & A systematic description & The land units within an area \\
\hline $\begin{array}{l}\text { The cadastre is simply an inventory of land } \\
\text { parcels described by spatial (maps) and }\end{array}$ & Land parcels & $\begin{array}{l}\text { Maps and text records } \\
\text { Maps: - }\end{array}$ & Inventory & - \\
\hline
\end{tabular}

pacels described by spatial (maps) and

textual (Certificates of Title) component

pertaining to the owner and use interests

(Dalrymple, 2005, p. 63).

A systematic and official description of all land

parcels within a jurisdiction, based

Text records: information concerning

owners, use interests

predominantly on a survey of their

boundaries represented on maps, which

includes, for each parcel, a unique identifier;

the description includes also text records on

the description includes also text records on
attributes of each parcel (Silva, 2005, p. 12).

A cadastre is a public record of rights in land.

Cadastral records consist of two parts: the

graphical description (known as a cadastral,

or property map) and the textual description

(Nkwae, 2006, p. 174)

Maps and text records 
Table 7

Criteria for analysis.

\begin{tabular}{|c|c|c|c|c|}
\hline Criteria for research method & $\begin{array}{l}\text { Criteria for data collection and } \\
\text { analysis method }\end{array}$ & Criteria for concept set & Criteria for theories & Criteria for validation \\
\hline $\begin{array}{l}\text { 1. Research method was } \\
\text { appropriate for stated } \\
\text { research problem. }\end{array}$ & $\begin{array}{l}\text { 1. Data collection method was } \\
\text { appropriate for the applied } \\
\text { research method. }\end{array}$ & $\begin{array}{l}\text { 1. Concept was defined in an } \\
\text { unambiguous and explicitly } \\
\text { way. }\end{array}$ & $\begin{array}{l}\text { 1. The theory/approach was } \\
\text { appropriate for the research } \\
\text { theme. }\end{array}$ & $\begin{array}{l}\text { 1.a The conclusions were stated } \\
\text { in defined terms and were } \\
\text { drawn from the data according } \\
\text { to the selected method (if not, } \\
\text { please reply } 1 . \mathrm{b} \text { ). }\end{array}$ \\
\hline $\begin{array}{l}\text { 2. Research method enabled to } \\
\text { reach aim and objectives of } \\
\text { research. } \\
\text { 3. Evidence confirms the } \\
\text { usefulness of the research } \\
\text { method. }\end{array}$ & $\begin{array}{l}\text { 2. Data analysis method was } \\
\text { appropriate for the applied } \\
\text { research method. }\end{array}$ & $\begin{array}{l}\text { 2. Concept definition can } \\
\text { adequately be adopted in other } \\
\text { jurisdictions. } \\
\text { 3. Concept definition is related } \\
\text { to established scientific } \\
\text { disciplines. } \\
\text { 4. Concept was defined with } \\
\text { neither over-broad nor } \\
\text { over-narrow approaches. }\end{array}$ & $\begin{array}{l}\text { 2. The concepts of the selected } \\
\text { theory/approach were defined } \\
\text { in an explicit and coherent way. } \\
\text { 3. Evidence and findings } \\
\text { corroborate the usefulness of } \\
\text { the theory/approach. }\end{array}$ & $\begin{array}{l}\text { 1.b. The reasons were } \\
\text { explained/discussed in the } \\
\text { dissertation. } \\
\text { 2. Reasons are given why } \\
\text { outcomes of the research can } \\
\text { be generalized or transferred to } \\
\text { other cases. }\end{array}$ \\
\hline
\end{tabular}

nonetheless, it does not give an explanation of system boundaries, system elements, their nature and dynamics.

In addition to these approaches, it is worth mentioning another approach of system engineering, namely Socio-Technical Systems (STS) which is being developed by researchers from the Delft University of Technology. The STS approach distinguishes between components of systems which are involving humans and those which are embedded in the society (Kroes et al., 2004). STS comprises three elements, namely technical elements, social elements, and actors. Its characteristic assertion is that explaining and designing the social element and the actor behavior needs approaches which differ from system engineering (see Kroes et al., 2004). Ottens (2004) firstly applied the STS approach to the cadastral domain. Stubkjær (2006) and Ottens and Stubkjær (2007) continued this effort and qualified cadastre as a STS.

Even though the array of approaches and methodologies of systems thinking has contributed to theory building for the domain of cadastral and land management, we think that a more elaborated cadastral theory is needed. As we mentioned above, conceptualization has played a major role in theorizing. Within the cadastral domain many initiatives have been made which contribute towards theory building, i.e. Modeling of Real Property Transactions (Zevenbergen et al., 2007); Core Cadastral Domain Model (Oosterom et al., 2006); Cadastral Template (Rajabifard et al., 2007); Ontological modeling approaches (Hess and Vaskovich, 2007; Hess and Schlieder, 2007; Navratil and Frank, 2007). Land Administration Guidelines (UNECE, 1996) and Guidelines on Real Estate Units and Identifiers (UNECE, 2004).

Despite those fruitful contributions, from our point of view, a coherent and universal core cadastral theory has not been built so far. As addressed in the introduction of the 'Joint COST Action G9 and FIG Commission 7 Workshop on Standardization in the Cadastral Domain', this is mainly due to 'the lack of a shared set of concepts and terminology. International standardization of these concepts (that is, the development of an ontology) could possibly resolve many of these communication problems' (Oosterom, 2004 , p. 1). As stated in the introduction of this section, theories are built with concepts. To serve their functions effectively, concepts have to be clear, precise, and agreed-upon (Frankfort-Nachmias and Nachmias, 1997, pp. 48-49). As appears from the reviewed dissertations there are several ambiguities in the definitions and usage of the core concepts, i.e. cadastre, cadastral system, land administration, and land management. For the purpose of demonstrating these ambiguities, we limit ourselves with the analyzed dissertations and only show some definitions of the concept of cadastre (see Table 6). To demonstrate both commonalities and dif- ferences we introduced elements of definitions, namely object of record, content and attributes, status and structure, and coverage. As the content of Table 6 indicates, a consensus exists, but a more thorough effort is needed for alleviating terminological inconsistencies.

Summarily, in the section 'Methodological and theoretical aspects of the reviewed dissertations', we presented an analysis of the methodological and theoretical aspects of the selected doctoral dissertation by demonstrating their research methods, data collection and analysis methods (cf. Table 2), research contributions (cf. Table 3) and validations of these contributions (cf. Table 4), and finally concepts and theories (cf. Table 5). This analysis enabled us to present recently applied research methodologies in a structured manner, and to discuss the appropriateness of these methodologies and theories for further research.

\section{Review of the draft taxonomy}

In this article we perform a two-steps analysis process. The first step, namely the above identification of the research domain and our analysis of methodological and theoretical aspects, provides a 'new analysis of known facts and findings', resulting in the 'development of a taxonomy for research methodology'. The taxonomy provides for an orderly schema consisting of taxonomic units, namely the components of research methodology including research method, data collection and analysis method, concept set and theories, and outcomes of the research. This taxonomy allowed to us to study, compare, and classify the components of research methodologies applied in the dissertations.

In the second step of analysis we looked for an agreement on the draft taxonomy. Therefore, we invited the researchers to improve the draft taxonomy by testing it by means of their own dissertations. In this analysis, we use the dissertations as the empirical base for improving the provided taxonomy. For this purpose, we prepared semi-structured questionnaires regarding (A) research methods, (B) data collection and analysis methods, (C) concept set, (D) applied theories and (E) validation (see Appendices A-E) and sent them to the researchers together with a previous version of the manuscript of the present article via e-mail. For each questionnaire, an array of criteria (see Table 7) and a grading scale (1: Weak, 3: Well, 5: Excellent) was developed. Then we asked the researchers to evaluate and grade theoretical and methodological aspects of their dissertations in order to test the validity of the taxonomy in relation to their research methodology. 
Among the contacted researchers, our co-operation request was replied by Dr. Charisse Griffith-Charles, Dr. Boipuso Nkwae, Dr. Maria Augusta Silva and Dr. Daniel Steudler. They participated in the second step of analysis by responding to and commenting on the submitted questionnaires. In general, responses showed agreement between the draft taxonomy and the perception of the individual researchers. However, Dr. Griffith-Charles listed the theories in the questionnaire form as (i) Evolutionary Theory of Land Rights, (ii) Sustainability of communal resource governance, (iii) Family land tenure systems, and (iv) Diffusion, whereas we summarized theories in Griffith-Charles (2004) the under the heading of 'property and land tenure theories'. As reported by Dr. Griffith-Charles, there are considerable overlaps and linkages between these theories that make the definitions and classifications possible to be done in a slightly different way.

\section{Concluding remarks}

In this article we analyzed ten dissertations which were written in English language, defended recently, and available on the World Wide Web. Although their themes varied, they all addressed (1) rights in land and (2) the official recording of these rights through national information systems.

The universe of discourse of the reviewed dissertations may be characterized based on by the factors which were analyzed through the case studies, namely:

- Geography,

- Institutional factors (history, cultural framework, legal framework including formal and informal law, social relationships within a society),

- Stakeholders (land registry, cadastre and other governmental organizations, parliaments, courts, private practitioners/professional, academics, households, parcel owners, non-governmental organizations/interest groups, and donor agencies),

- Procedures (i.e., adjudication, transfer, subdivision),

- Technology (i.e., surveying and mapping devices, information systems).
From the point of view of methodological contribution, a taxonomy of research methodology components was developed as basis for analysis of the dissertations. The analysis demonstrated a notable amount of commonality among the doctoral research projects in terms of methodology. Moreover, we invited the researchers to take part in the analysis to establish - as far as possible - a shared understanding of the taxonomy. Although the number of respondents was small, a basis has been established for further collective analyses which contribute towards establishing a research community. The main contribution of the present article, namely the taxonomy of research methodology, may also be used for further individual research and indeed for guiding Ph.D. level students who aim to perform research in the field of cadastral development.

A conclusion drawn from the inquiry is the fact that social and behavioral science methods are applied in research which is predominantly performed by a faculty of geodetic surveyors. In an epoch favoring multi-disciplinary research, this may be considered trivial. We rather take the observation as evidence of a shared strive for scientific rigor within our research domain, which we see as a precondition for a healthy dialogue with established university disciplines.

Finally, we iterate that concepts are the building blocks of theory. As we have observed in the reviewed dissertations, a limited consensus exists on core concepts and used terminology and as we have shown (Table 6), it is possible to pursue a shared set of concepts which might contribute towards further theory building for the cadastral research domain.

\section{Acknowledgements}

The present article is a part of the post-doc research project of the first author, supported by the Scientific and Technological Research Council of Turkey (TÜBITAK) and hosted by Aalborg University, Department of Development and Planning. The authors would like to acknowledge the organizations for their supports. The authors also wish to acknowledge to Dr. Charisse Griffith-Charles, Dr. Boipuso Nkwae, Dr. Maria Augusta Silva and Dr. Daniel Steudler for their contributions to this article. 
Appendix A. Questionnaire form for research method.

\begin{tabular}{|c|c|c|c|c|}
\hline \multirow{11}{*}{ Research methods } & \multicolumn{4}{|c|}{$\begin{array}{l}\text { Do you agree with the definitions and classifications of research methods in the article? } \\
\text { If not, please indicate your opinions, or suggestions below in the general thoughts section. }\end{array}$} \\
\hline & \multicolumn{4}{|c|}{ Please indicate research methods that you conducted in your doctoral research. } \\
\hline & \multicolumn{2}{|c|}{ Research methods } & \multicolumn{2}{|c|}{ Please specify significant quoted/referred preceding work } \\
\hline & Research method 1 & & & \\
\hline & Research method 2 & & & \\
\hline & Research method 3 & & & \\
\hline & Research method 4 & & & \\
\hline & Research method 5 & & & \\
\hline & Research method 6 & & & \\
\hline & Research method 7 & & & \\
\hline & Research method 8 & & & \\
\hline Evaluation criteria & $\begin{array}{l}\text { 1. Research method was app } \\
\text { 2. Research method enabled } \\
\text { 3. Evidence confirms the use }\end{array}$ & $\begin{array}{l}\text { e for stated } \\
\text { ch aim and o } \\
\text { of the rese }\end{array}$ & $\begin{array}{l}\text { problem. } \\
\text { sof research. } \\
\text { hod. }\end{array}$ & \\
\hline \multirow{11}{*}{ Evaluation of research methods } & \multicolumn{4}{|c|}{ Please evaluate each of these methods according criteria given below } \\
\hline & Evaluation & Criteria 1 & Criteria 2 & Criteria 3 \\
\hline & Evaluation for research method 1 & & & \\
\hline & Evaluation for research method 2 & & & \\
\hline & Evaluation for research method 3 & & & \\
\hline & Evaluation for research method 4 & & & \\
\hline & Evaluation for research method 5 & & & \\
\hline & Evaluation for research method 6 & & & \\
\hline & Evaluation for research method 7 & & & \\
\hline & Evaluation for research method 8 & & & \\
\hline & $\begin{array}{l}\text { Cumulative evaluation for all } \\
\text { used research methods }\end{array}$ & & & \\
\hline \multirow[b]{2}{*}{ General thoughts } & \multicolumn{4}{|c|}{ Please indicate your thoughts on research methods, if explanation is needed. } \\
\hline & & & & \\
\hline
\end{tabular}




\section{Appendix B. Questionnaire form for data collection and data analysis method.}

\begin{tabular}{|c|c|c|c|}
\hline \multirow{11}{*}{$\begin{array}{l}\text { Data collection and analysis } \\
\text { methods }\end{array}$} & \multicolumn{3}{|c|}{$\begin{array}{l}\text { Do you agree with the definitions and classifications of data collection and analysis methods in the article? } \\
\text { If not, please indicate your opinions, or suggestions below in the general thoughts section. }\end{array}$} \\
\hline & \multicolumn{3}{|c|}{ Please indicate data collection methods that you performed in your doctoral research. } \\
\hline & \multicolumn{2}{|c|}{ Data collection and data analysis methods } & Please specify significant quoted/referred preceding work \\
\hline & Data collection method 1 & & \\
\hline & Data collection method 2 & & \\
\hline & Data collection method 3 & & \\
\hline & Data collection method 4 & & \\
\hline & Data analysis method 1 & & \\
\hline & Data analysis method 2 & & \\
\hline & Data analysis method 3 & & \\
\hline & Data analysis method 4 & & \\
\hline Evaluation criteria & $\begin{array}{l}\text { 1. Data collection method was app } \\
\text { 2. Data analysis method was appro }\end{array}$ & $\begin{array}{l}\text { iate for the } \\
\text { ate for the a }\end{array}$ & $\begin{array}{l}\text { ied research method. } \\
\text { d research method. }\end{array}$ \\
\hline \multirow{5}{*}{$\begin{array}{l}\text { Evaluation of data collection and } \\
\text { analysis methods }\end{array}$} & \multicolumn{3}{|c|}{ Please evaluate each of these methods according criteria given below } \\
\hline & Evaluation & Criteria 1 & Criteria 2 \\
\hline & Evaluation for data collection method 1 & & \\
\hline & Evaluation for data collection method 2 & & \\
\hline & Evaluation for data collection method 3 & & \\
\hline \multirow{6}{*}{$\begin{array}{l}\text { Scale } \\
\text { 1: Weak } \\
\text { 3: Well } \\
\text { 5: Excellent }\end{array}$} & Evaluation for data collection method 4 & & \\
\hline & Evaluation for data analysis method 1 & & \\
\hline & Evaluation for data analysis method 2 & & \\
\hline & Evaluation for data analysis method 3 & & \\
\hline & Evaluation for data analysis method 4 & & \\
\hline & $\begin{array}{l}\text { Cumulative evaluation for used data } \\
\text { collecting and analysis methods }\end{array}$ & & \\
\hline & \multicolumn{3}{|c|}{ Please indicate your thoughts on data collection and data analysis methods, if explanation is needed. } \\
\hline General thoughts & & & \\
\hline
\end{tabular}


Appendix C. Questionnaire form for concept set.

\begin{tabular}{|c|c|c|c|c|c|}
\hline \multirow{11}{*}{ Concept set } & \multicolumn{5}{|c|}{$\begin{array}{l}\text { Do you agree with the definition of concept in the article? } \\
\text { If not, please indicate your opinions, or suggestions below in the general thoughts section. }\end{array}$} \\
\hline & \multirow{2}{*}{\multicolumn{5}{|c|}{ Please indicate main concepts which were defined, preferred or proposed with your doctoral research. }} \\
\hline & & & \multirow{2}{*}{\multicolumn{3}{|c|}{ Please specify significant quoted/referred preceding work }} \\
\hline & \multicolumn{2}{|l|}{ Concept 1} & & & \\
\hline & \multirow{2}{*}{\multicolumn{2}{|c|}{$\begin{array}{l}\text { Concept } 2 \\
\text { Concept } 3\end{array}$}} & & & \\
\hline & & & & & \\
\hline & \multicolumn{2}{|l|}{ Concept 4} & & & \\
\hline & \multicolumn{2}{|l|}{ Concept 5} & & & \\
\hline & \multirow{2}{*}{\multicolumn{2}{|c|}{ Concept 6}} & & & \\
\hline & \multirow{2}{*}{\multicolumn{2}{|c|}{ Concept 7}} & & & \\
\hline & & & & & \\
\hline Evaluation criteria & \multirow{2}{*}{\multicolumn{5}{|c|}{$\begin{array}{l}\text { 1. Concept was defined in an unambiguous and explicitly way. } \\
\text { 2. Concept definition can adequately be adopted in other jurisdictions. } \\
\text { 3. Concept definition is related to established scientific disciplines. } \\
\text { 4. Concept was defined with neither over-broad nor over-narrow approaches. }\end{array}$}} \\
\hline \multirow[b]{3}{*}{ Evaluation of definitions } & & \multicolumn{4}{|c|}{ Please evaluate each of these definitions according criteria given below. } \\
\hline & Evaluation & Criteria 1 & Criteria 2 & Criteria 3 & Criteria 4 \\
\hline & \multirow{2}{*}{\multicolumn{2}{|c|}{$\begin{array}{l}\text { Evaluation for concept } 1 \\
\text { Evaluation for concept } 2\end{array}$}} & & & \\
\hline \multirow{7}{*}{$\begin{array}{l}\text { Scale } \\
\text { 1: Weak } \\
\text { 3: Well } \\
\text { 5: Excellent }\end{array}$} & & & & & \\
\hline & \multicolumn{2}{|l|}{$\begin{array}{l}\text { Evaluation or concept } 2 \\
\text { Evaluation for concept } 3\end{array}$} & & & \\
\hline & \multicolumn{2}{|l|}{ Evaluation for concept 4} & & & \\
\hline & \multicolumn{2}{|l|}{ Evaluation for concept 5} & & & \\
\hline & \multicolumn{2}{|l|}{ Evaluation for concept 6} & & & \\
\hline & \multirow{2}{*}{\multicolumn{2}{|c|}{ Evaluation for concept 7}} & & & \\
\hline & & & & & \\
\hline \multirow[b]{2}{*}{ General thoughts } & \multicolumn{5}{|c|}{ Please indicate your thoughts on concepts, if explanation is needed. } \\
\hline & & & & & \\
\hline
\end{tabular}


Appendix D. Questionnaire form for theories.

\begin{tabular}{|c|c|c|c|c|}
\hline \multirow{11}{*}{ Theories } & \multirow{2}{*}{\multicolumn{4}{|c|}{$\begin{array}{l}\text { Do you agree with the definitions and classifications of theories in the article? } \\
\text { If not, please indicate your opinions, or suggestions below at general thoughts section. }\end{array}$}} \\
\hline & & \multicolumn{3}{|c|}{ Please indicate main theories which you preferred in your doctoral research. } \\
\hline & \multicolumn{2}{|c|}{ Theories } & \multicolumn{2}{|c|}{ Please specify significant quoted/referred preceding work } \\
\hline & & & \\
\hline & \multicolumn{2}{|l|}{$\begin{array}{l}\text { Theory } 1 \\
\text { Theory } 2\end{array}$} & & \\
\hline & \multirow{2}{*}{\multicolumn{2}{|c|}{ Theory 3}} & & \\
\hline & & & & \\
\hline & \multicolumn{2}{|l|}{$\begin{array}{l}\text { Theory } 4 \\
\text { Theory } 5\end{array}$} & & \\
\hline & & & \\
\hline & \multicolumn{2}{|l|}{ Theory 7} & & \\
\hline & \multicolumn{2}{|l|}{ Theory 8} & & \\
\hline Evaluation criteria & \multicolumn{4}{|c|}{$\begin{array}{l}\text { 1. The theory/approach was appropriate for the research theme. } \\
\text { 2. The concepts of the selected theory/approach were defined in an explicit and coherent way. } \\
\text { 3. Evidence and findings corroborate the usefulness of the theory/approach. }\end{array}$} \\
\hline \multirow{5}{*}{ Evaluation of theories } & \multicolumn{4}{|c|}{ Please evaluate each of these theories according criteria given below. } \\
\hline & Evaluation & Criteria 1 & Criteria 2 & Criteria 3 \\
\hline & Evaluation for theory 1 & & & \\
\hline & Evaluation for theory 2 & & & \\
\hline & Evaluation for theory 3 & & & \\
\hline \multirow{6}{*}{$\begin{array}{l}\text { Scale } \\
\text { 1: Weak } \\
\text { 3: Well } \\
\text { 5: Excellent }\end{array}$} & Evaluation for theory 4 & & & \\
\hline & Evaluation for theory 5 & & & \\
\hline & Evaluation for theory 6 & & & \\
\hline & Evaluation for theory 7 & & & \\
\hline & Evaluation for theory 8 & & & \\
\hline & $\begin{array}{l}\text { Cumulative evaluation for } \\
\text { all used theories }\end{array}$ & & & \\
\hline \multirow[b]{2}{*}{ General thoughts } & \multicolumn{4}{|c|}{ Please indicate your thoughts on theories, if explanation is needed. } \\
\hline & & & & \\
\hline
\end{tabular}




\section{References}

Addams, H., Proops, J. (Eds.), 2000. Social Discourse and Environmental Policy: An Application of Q Methodology. Edward Elgar, Cheltenham, p. 240.

Auzins, A., 2007. Towards more efficient transaction procedures in Latvia. In: Zevenbergen, J., Frank, A., Stubkjær, E. (Eds.), Real Property Transactions. IOS Press, Amsterdam, pp. 81-98.

Barbour, J.D., 2006. Ethnography. In: English, F.W. (Ed.), Encyclopedia of Educational Leadership and Administration. Sage Publications, http://www.sageereference.com/edleadership/Article_n213.html (accessed 12 September 2008).

Barnes, G., 1994. Current cadastral system issues and challenges in developing countries. South African Journal of Surveying and Mapping 22 (5), 279-286.

Barnes, G., Greening, T., Barthel, K., 2007. Pioneering a rapid and cheap GPS cadastral surveying methodology for developing countries. Geomatica 61 (4), 431-443.

Barry, M., 1999. Evaluating cadastral systems in periods of uncertainty: a study of Cape Town's Xhosa-speaking communities. Ph.D. Dissertation. University of Natal.

Barry, M.B., Fourie, C., 2002. Analyzing cadastral systems in uncertain situations: a conceptual framework based on soft systems theory. International Journal of Geographical Information Science 16 (1), 23-40.

Bittner, S., 2001. An agent-based model of reality in a cadastre. Ph.D. Thesis. Technical University Vienna.

Bittner, S., Frank, A.U., 2002. A formal model of correctness in a cadastre. Computers, Environment and Urban Systems 26, 465-482.

Blaikie, N., 2000. Designing Social Research. Polity Press, Cambridge, p. 338.

Bloor, M., Wood, F., 2006. Keywords in Qualitative Methods. A Vocabulary of Research Concepts. Sage Publication, London, p. 195

Bogaerts, T., 1999. Cadastral systems: critical success factors. In: Proceedings of the 21 st Urban Data Management Symposium 1999, Venice, 1-12.

Bott, J.P., 2006. Case study method. In: Rogelberg, S.G. (Ed.), Encyclopedia of Industrial and Organizational Psychology. Sage Publications, http://www.sageereference.com.zorac.aub.aau.dk/organizationalpsychology/Article_n29.html (accessed 13 September 2008).

Bruce, J., 1993. Review of tenure terminology. Land Tenure Center Report, University of Wisconsin. http://agecon.lib.umn.edu/ltc/ltctb01.pdf (accessed 15 February 2008)

Cashin, S.M., McGrath, G., 2006. Establishing a modern cadastral system within a transition country: consequences for the Republic of Moldova. Land Use Policy 23, 629-642.

Checkland, P., 1981. Systems Thinking, Systems Practice. John Wiley \& Sons, Toronto \& New York, p. 330.

Checkland, P., Scholes, J., 1990. Soft Systems Methodology in Action. John Wiley \& Sons, Toronto \& New York, p. 329.

Dale, P.F., 1979. A Systems view of the Cadastre. Survey Review 25 (191), 28-32.

Dalrymple, K., 2005. Expanding rural land tenures to alleviate poverty. Ph.D. Dissertation. University of Melbourne. http://www.geom.unimelb.edu.au/research/ SDI_research/publications/Dalrymple\%20PhD\%20Thesis.pdf(accessed 15 February 2008).

Danermark, B., Ekström, M., Jacobsen, L., Karlsson, J., 2002. Explaining Society: Critical Realism in the Social Sciences. Routledge, London, p. 240.

Effenberg, W., 2001. Spatial Cadastral Information Systems - The maintenance of digital cadastral maps. Ph.D. Dissertation. University of Melbourne. http://www.geom.unimelb.edu.au/research/publications/IPW/Wolfgang_thesis PDF (accessed 15 February 2008).

Feder, G., Onchan, T., 1987. Land ownership security and farm investment in Thailand. American Journal of Agricultural Economics 69 (2), 311-320.

Feder, G., Nishio, A., 1999. The benefits of land registration and titling: economic and social perspectives. Land Use Policy 15 (1), 25-43.

FIG, 1995. Statement on the cadastre. Report prepared for the International Federation of Surveyors (FIG) by Commission 7, Cadastre and Land Management. http://www.fig7.org.uk/publications/cadastre/statementoncadastre.html (accessed 15 February 2008)

Frankfort-Nachmias, C., Nachmias, D., 1997. Research Methods in the Social Sciences. Arnold, London, p. 600.

Geist, M.R., Lahman, M.K.E., 2008. Mixed methodology research. In: Leong, F.T.L. (Ed.), Encyclopedia of Counseling. Sage Publications, http://www.sageereference.com.zorac.aub.aau.dk/counseling/Article_n101.html (accessed 12 September 2008).

Gibson, N., 2003. Action research. In: Lewis-Beck, M. (Ed.), Encyclopedia of Social Science Research Methods. Sage Publications, http://www.sageereference.com/socialscience/Article_n4.html (accessed 12 September 2008).

Gile, D. 2001. Selecting a topic for PhD research in interpreting. In: Gile, D., Dam, H.V. Dubslaff, F., Martinsen, B., Scjoldager, A. (Eds.), Getting Started in Interpreting Research. John Benjamins Publishing, Amsterdam, pp. 2-22.

Griffith-Charles, C., 2004. The impact of land titling on land transaction activity and registration system sustainability: a case study of St. Lucia. Ph.D. Dissertation. University of Florida. http://etd.fcla.edu/UF/UFE0006631/griffithcharles_c.pdf (accessed 15 February 2008).

Henssen, J.L.G., Williamson, I.P., 1990. Land registration, cadastre and its interaction; a world perspective. In: Proceedings XIX FIG Congress, Helsinki 1990, pp. 14-43. 
Hess, C., Schlieder, C., 2007. Ontology-based development of reference processes. In: Zevenbergen, J., Frank, A., Stubkjær, E. (Eds.), Real Property Transactions. IOS Press, Amsterdam, pp. 203-218.

Hess, C., Vaskovich, M., 2007. Ontology engineering for comparing property transactions. In: Zevenbergen, J., Frank, A., Stubkjær, E. (Eds.), Real Property Transactions. IOS Press, Amsterdam, pp. 183-201.

Holstein, L.C., 1987. Considerations for land registration improvement for less developed countries. Survey Review 29 (223), 19-27.

Hunter, M.G., 2004. Qualitative research in information systems: an exploration of methods. In: Whitman, M.E., Woszczynski, A.B. (Eds.), The Handbook of Information Systems Research. Idea Group Publishing, London, pp. 291-304.

Iversen, G.R., 2007. Quantitative research. In: Lewis-Beck, M.S., Bryman, A., Liao, T.F. (Eds.), The Sage Encyclopedia of Social Science Research Methods. Thousand Oaks, London, http://www.sageereference.com/socialscience/Article_n787.html (accessed 15 February 2008)

Kalabamu, F., 2000. Land tenure and management reforms in East and Southern Africa-the case of Botswana. Land Use Policy 17, 305-319.

Kaufmann, J., Steudler, D., 1998. Cadastre 2014-A Vision for a Future Cadastral System. Rüdlingen and Bern, Switzerland, 51 p. http://www.fig.net/cadastre2014/translation/c2014-english.pdf (accessed 15 February 2008).

Kroes, P.A., Franssen, M.P.M., Poel, I.V.D., Ottens, M., 2004. Engineering systems as hybrid, socio-technical systems. In: Paper presented at Engineering Systems Symposium, Cambridge Marriott, USA, 29-31 March.

Lahman, M.K.E., Geist, M.R., 2008. Qualitative methodologies. In: Leong, F.T.L. (Ed.), Encyclopedia of Counseling. Sage Publications, http://www.sageereference.com/counseling/Article n117.html (accessed 12 September 2008).

Langhout, R.D., 2005. Qualitative methods. In: Salkind, N.J. (Ed.), Encyclopedia of Human Development. Sage Publications, http://www.sageereference.com.zorac.aub.aau.dk/humandevelopment/Article_n510.html (accessed 15 September 2008)

Lewis-Beck, M.S., 2007. Case. In: Lewis-Beck, M.S., Bryman, A., Liao, T.F. (Eds.), The Sage Encyclopedia of Social Science Research Methods. Thousand Oaks, London, http://www.sage-ereference.com/socialscience/Article_n90.html (accessed 7 April 2008)

Marshall, G., 1998. A dictionary of sociology. Oxford University Press, New York.

McLaughlin, J., Nichols, S., 1987 March. Parcel-based land information systems. Surveying and Mapping, 11-29.

Mueller, M., 2008. Transformations of cadastral descriptions with incomplete information into maps. Transactions in GIS 12 (1), 83-101.

Nainggolan, D., 2007. Visual discourse analysis for exploring socioecological system management dynamics. The 2007 Amsterdam Conference on the Human Dimensions of Global Environmental Change. http://www.2007amsterdamconference.org/Downloads/AC2007_Nainggolan. pdf (accessed 16 June 2008)

Navratil, G., Frank, A.U., 2004. Processes in a cadastre. Computers, Environment and Urban Systems 28, 471-486.

Navratil, G., Frank, A., 2007. Hierarchies in subdivision processes. In: Zevenbergen, J., Frank, A., Stubkjær, E. (Eds.), Real Property Transactions. IOS Press, Amsterdam, pp. 221-235.

Nichols, S.E., 1993. Land registration: managing information for land administration. PhD. Dissertation. University of New Brunswick. http://gge.unb.ca/Pubs/TR168.pdf (accessed 15 February 2008).

Nkwae, B., 2006. Conceptual framework for modelling and analysing periurban land problems in Southern Africa. Ph.D. Dissertation. University of New Brunswick. http://gge.unb.ca/Pubs/TR235.pdf (accessed 15 February 2008).

Oosterom, P.J.M., 2004. Introduction. In: Proceedings of the Workshop on Standardization on the Cadastral Domain, Bamberg, Germany, 9-10 December http://www.fig.net/commission7/bamberg_2004/introduction.pdf(accessed 24 September 2008)

Oosterom, P.J.M., Lemmen, C.H.J., 2001. Spatial data management on a very large cadastral database. Computers, Environment and Urban Systems 25, 509-528.

Oosterom, P.J.M., Lemmen, C.H.J., Ingvarsson, T., Molen, P.v.d., Ploeger, H., Quak, W., Stoter, J., Zevenbergen, J., 2006. The core cadastral domain model. Computers, Environment and Urban Systems 30, 627-660.

Ottens, M., 2004. The cadastral system as a socio-technical system. In: Proceedings of the Workshop on Standardization on the Cadastral Domain, Bamberg, Germany, 9-10 December. http://www.fig.net/commission7/ bamberg_2004/papers/ts_01_03_ottens.pdf (accessed 15 January 2008).

Ottens, M., Stubkjær, E., 2007. A socio-technical analysis of the cadastral system. In: Zevenbergen, J., Frank, A., Stubkjær, E. (Eds.), Real Property Transactions. IOS Press, Amsterdam, pp. 143-166.

Park, M.M., 2003. The effect of adverse possession on part of a registered title land parcel. Ph.D. Dissertation. University of Melbourne. http://www.geom.unimelb.edu.au/research/publications/MMP_PhD.pdf (accessed 7 April 2008)

Pickard, A.J., 2007. Research Methods in Information. Facet Publishing, London, p. 329 .

Platt, J., 2007. Participant observation. In: Lewis-Beck, M.S., Bryman, A., Liao, T.F. (Eds.), The Sage Encyclopedia of Social Science Research Methods. Thousand Oaks, London, http://www.sage-ereference.com/socialscience/ Article_n692.html (accessed 7 April 2008).
Rajabifard, A., Williamson, I., Steudler, D., Binns, A., King, M., 2007. Assessing the worldwide comparison of cadastral systems. Land Use Policy 24, 275-288.

Rakai, M.E.T., 2005. A neutral framework for modeling and analysing aboriginal land tenure systems. Ph.D. Dissertation. University of New Brunswick. http://gge.unb.ca/Pubs/TR227.pdf (accessed 15 February 2008)

Salamon, S., 1998. Cultural Dimensions of Land Tenure in the United States. In: Jacobs, H. (Ed.), Who Owns America? Social Conflict over Property Rights, University of Wisconsin Press, Wisconsin, pp. 159-181.

Sandelowski, M., 2007. Qualitative research. In: Lewis-Beck, M.S., Bryman, A., Liao, T.F. (Eds.), The Sage Encyclopedia of Social Science Research Methods. Thousand Oaks, London, http://www.sageereference.com/socialscience/Article_n783.html (accessed 7 April 2008)

Sarantakos, S., 2005. Social Research. Palgrave Macmillian, New York, p. 464.

Schneider, L.C., 2007. Research methods. In: Robbins, P. (Ed.), Encyclopedia of Environment and Society. Sage Publications, http://www.sageereference.com/environment/Article_n909.html (accessed 12 September 2008)

Sikor, T., 2006. Politics of rural land registration in post-socialist societies: contested titling in villages of Northwest Vietnam. Land Use Policy 23, 617-628.

Silva, M.A., 2005. Modelling causes of cadastral development-cases in Portuga and Spain during the last two decades. Ph.D. Dissertation. Aalborg University. http://www.plan.aau.dk/ masilva/MariaASilva_PhD_Thesis.pdf (accessed 15 February 2008)

Silva, M.A., Stubkjær, E., 2002. A review of methodologies used in research on cadastral development. Computers, Environment and Urban Systems 26 403-423.

Simpson, S.R., 1976. Land Law and Registration. Cambridge University Press, London, p. 726.

Sproull, N.L., 1995. Handbook of Research Methods. Scarecrow Press, Lanhalm, p. 449.

Steudler, D., Williamson, I.P., Kaufmann, J., Grant, D.M., 1997. Benchmarking Cadastral Systems. The Australian Surveyor 42 (3), 87-106.

Steudler, D., Kaufmann, J. (Eds.), 2002. Benchmarking Cadastral Systems. International Federation of Surveyors, Denmark, 76 pp. http://www.fig.net/pub/compub/FIG2002BenchmarkingCadastralSystems.pdf (accessed 3 April 2008).

Steudler, D., Williamson, I.P., Rajabifard, A., 2003. The development of a cadastral template. Journal of Geospatial Engineering 5 (1), 39-47.

Steudler, D., 2004. A framework for the evaluation of land administration systems. Ph.D. Thesis. University of Melbourne. http://www.geom. unimelb.edu.au/research/publications/PhDThesisDanielS.pdf (accessed 15 February 2008)

Steudler, D., Rajabifard, A., Williamson, I.P., 2004. Evaluation of land administration systems. Land Use Policy 21, 371-380.

Stoter, J., Oosterom, P.J.V., 2003. Cadastral registration of real estate objects in three dimensions. URISA 15 (2), 47-56.

Stoter, J.E., 2004. 3D Cadastre. Netherlands Geodetic Commission, Delft http://www.ncg.knaw.nl/Publicaties/Geodesy/pdf/57Stoter.pdf (accessed 15 February 2008).

Stubkjær, E., 2006, The cadastre as a socio-technical system. GIS Development. http://www.gisdevelopment.net/magazine/years/2006/june/26_1.htm (accessed 15 January 2008).

Stubkjær, E., Lavrac, I., Gysting, C., 2007. Towards national real estate accounts-the case of Denmark and other European jurisdictions. In: Zevenbergen, J., Frank, A, Stubkjær, E. (Eds.), Real Property Transactions. IOS Press, Amsterdam, pp. 119-137.

Stuckenschmidt, H., Stubkjær, E., Schlieder, C. (Eds.), 2003. The Ontology and Modelling of Real Estate Transactions. Ashgate, Aldershot, p. 186.

Ting, L.A, 2002. Principles for an integrated land administration system to support sustainable development. Ph.D. Dissertation. University of Melbourne http://www.geom.unimelb.edu.au/research/publications/LisaTing2002PhDThesis.pdf (accessed 15 January 2008).

Törhönen, M.P., 2003a. Sustainable land tenure and land registration in developing countries. Ph.D. Dissertation. Helsinki University of Technology. http://lib.tkk.fi/Diss/2003/isbn9512264919/ (accessed 15 January 2008).

Törhönen, M.P., 2003b. Sustainable land tenure and land registration in developing countries, including a historical comparison with an industrialised country. Computers, Environment and Urban Systems 28 (5), 545-586.

Tuladhar, A.M., 2004. Parcel-based geo-information system: concepts and guidelines. Ph.D. Dissertation. International Institute for Geo-Information Science and Earth Observation. http://www.itc.nl/library/Papers_2004/phd/tuladhar.pdf/ (accessed 15 January 2008)

UNECE, 1996. Land administration guidelines. http://www.unece. org/hlm/wpla/publications/laguidelines.html (accessed 15 January 2008).

UNECE, 2004. Guidelines on real property units and identifiers. www.unece. org/env/documents/2005/wpla/Guidelines_On_Real_Property_Identifiers.pdf (accessed 15 January 2008).

Van Loenen, B., 2006. Developing geographic information infrastructures-The role of information policies. Ph.D. Dissertation. Delft University of Technology. http://www.library.tudelft.nl/ws/search/publications/search/metadata/index. htm?docname=088301 (accessed 15 January 2008).

Vitikainen, A., 2007. Transaction costs concerning real property-the case of Finland. In: Zevenbergen, J., Frank, A., Stubkjær, E. (Eds.), Real Property Transactions. IOS Press, Amsterdam, pp. 101-117.

Wilcox, D.J., 1984. Proposed map accuracy standards for a multipurpose cadastre. Computers, Environment \& Urban Systems 9 (2-3), 203-207. 
G Model

Williamson, I.P., 2001. Land administration "best practice" providing the infrastructure for land policy implementation. Land Use Policy 18, 297-307.

Yin, R.K., 1989. Case Study Research: Design and Methods. Sage, London, p. 181.

Yin, R.K., 2003. Case Study Research: Design and Methods, 3rd ed. Sage, London, p. 200

Zevenbergen, J., Bogaerts, T., 2000. Alternative approaches for successful cadastral systems. In: Proceedings of the 22nd Urban and Regional Data Management Symposium UDMS, Delft, UDMS/TU Delft, pp. III.67III.76.
Zevenbergen, J., 2002. Systems of Land Registration, Aspects and Effects. Netherlands Geodetic Commission, Delft, http://www.ncg. knaw.nl/Publicaties/Geodesy/pdf/51Zevenbergen.pdf (accessed 15 February 2008).

Zevenbergen, J., 2004. A systems approach to land registration and cadastre. Nordic Journal of Surveying and Real Estate Research 1, 11-24.

Zevenbergen, J., Frank, A., Stubkjær, E. (Eds.), 2007. Real Property Transactions: Procedures, Transaction Costs and Models. IOS Press, Amsterdam, p. 279.

Please cite this article in press as: Çağdaş, V., Stubkjær, E., Doctoral research on cadastral development. Land Use Policy (2008), doi:10.1016/j.landusepol.2008.10.012 